UNITED STATES

DEPARTMENT OF THE INTERIOR

GEOLOG ICAL SURVEY

\title{
Water-Resources Appraisal of the Galena Creek Basin, Washoe County, Nevada
}

By Terry Katzer, Timothy J. Durbin, and Douglas K. Maurer

Open-File Report $84-433$

Prepared in cooperation with the

NEVADA DIVISION OF WATER RESOURCES

Carson City, Nevada 
UNITED STATES DEPARTMENT OF THE INTERIOR

WILLIAM P. CLARK, Secretary

GEOLOGICAL SURVEY

Dallas L. Peck, Director

For additional information write to:

U.S. Geological Survey Room 227, Federal Building

705 North Plaza Street

Carson City, NV 89701
Copies of this report may be purchased from:

Open-File Services Section

U.S. Geological Survey

Box 25425, Federal Center Denver, CO 80225

Call (303) 234-5888 for ordering information 
INTRODUCTION -- ---------

Purpose and scope --

Significance of numerical values -

Availability of data -

Acknowledgments --

Numbering system for hydrologic sites -

DESCRIPTION OF THE STUDY AREA - - 3

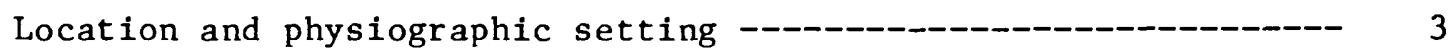

Hydrogeologic setting ------ 3

General lithologic and water-bearing character

of geologic units -- 3

Consolidated rocks - 3

Unconsolidated deposits - 7

General structural features -- 7

Thickness of unconsolidated deposits --_-_-_-_-_-_-_--- 10

Gravity measurements - 10

Reduction of gravity data --_-_- 12

Interpretation of gravity data - 12

Hydrologic setting - -

Source of water --_-_-_-_ 12

Ground-water levels --- 15

Sources of data --_--_- 15

Vertical electrical soundings --_-_-_-_-_-_-_- 15

Ground-water recharge, storage, and discharge --_--_-_--- 19

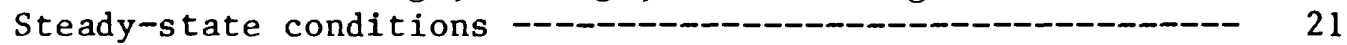

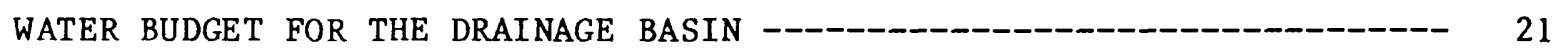

The water-budget equation

Precipitation --

Precipitation-altitude relation -

Precipitation map - 25

Evapotranspiration - 25

Primary evapotranspiration - 28

Relation between precipitation and runoff---_--- 28

Relation between precipitation and evapotranspiration - 31

Evapotranspiration map

Secondary evapotranspiration - 36

Surface-water outflow -

Ground-water outflow -- 38 
WATER BUDGET FOR THE GROUND-WATER BASIN - 38

The water-budget equation 38

Ground-water outflow - 40

Pumpage - 40

Ground-water recharge - 40

Secondary recharge - 42

Applied irrigation water 42

Conveyance loss - 42

Domestic use - 42

Primary recharge - 42

Distribution of primary ground-water recharge - 43

Seepage from Galena Creek channel - 43

Diffuse sources of primary recharge

Underflow into ground-water basin beneath Galena Creek ---- 46

WATER-BUDGE T SUMMARY -

Model development

Steady-state simulation _- 46

Governing equation - 48

General features of the model 48

Model boundaries - 50

Recharge and discharge _- 50

Transmissivity - 50

Model analysis _- 51

Accuracy of the hydrologic data base

and resulting estimates 54

SUMMARY - 55

REFERENCES CITED - 58 


\section{ILLUSTRATIONS}

Figures 1-3. Maps showing:

1. Location and general physiographic

features of the study area 4

2. Definition of the drainage and

ground-water basins

3. Generalized geology - 6

4. Graph showing specific capacity

of selected wells - 8

5. Schematic hydrogeologic section from

west to east through the study area

6-11. Maps of the eastern part of the study area showing:

6. Estimated thickness of unconsolidated deposits -- 11

7. Complete Bouguer gravity anomalies

8. Residual gravity anomalies - 14

9. Depth to ground water, spring 1979, and general direction of ground-water movement

10. Altitude of ground-water level, spring $1979 \ldots 17$

11. Hydrologic data sites 18

12. Water-level hydrograph for well N17 E19 02CDDDI -

13. Schematic representation of water budget

for drainage basin - 23

14. Graph showing relation between mean annual precipitation and altitude -_-_-_-_-_-_-_-_-_-_-_ 26

15. Map showing estimated areal distribution of mean annual precipitation 
16,17. Graphs showing:

16. Relation between mean annual precipitation and water runoff

17. Comparison between measured and computed water runoff -

18. Map showing estimated distribution of mean annual runoff and location of recharge areas

19. Graph showing relation between estimated mean annual precipitation and evapotranspiration

20. Map showing estimated areal distribution of mean annual evapotranspiration

21. Schematic flow diagram for lower reach of Galena Creek, showing estimated gains and losses ---_--------

22. Schematic representation of water budget for ground-water basin

23-26. Maps showing:

23. General locations and amounts of primary ground-water recharge and discharge and

24. Boundary and grid for ground-water model

25. Saturated thickness of the unconsolidated deposits

26. Computed steady-state ground-water levels for recharge and discharge conditions as of 1979 
TABLES

Table 1. Depth to water table calculated from soundings of vertical electrical resistivity - 20

2. Mean annual water budget for the drainage basin -

3. Data on stream-gaging sites used in developing the relation between precipitation and runoff -

4. Mean annual water budget for the ground-water basin --- 41

5. Estimates of primary ground-water recharge from diffuse sources

6. Summary of mean annual water budget for the Galena Creek ground-water basin

7. Water-level altitude in wells, April 30-

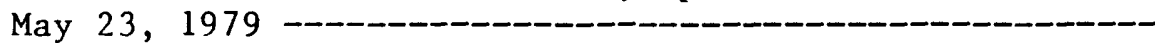




\section{CONVERSION FACTORS}

Only the "inch-pound" system is used in this report. Conversion factors from inch-pound to International (metric) units are listed below.

Multiply

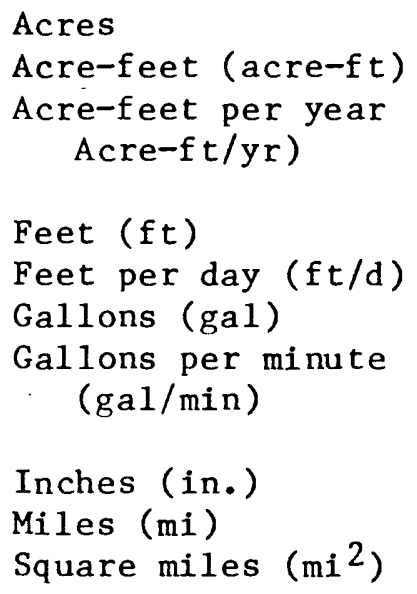

By
4,047
0.001233
0.001233
0.3048
0.3048
3.785
0.06309
25.40
1.609
2.590

To obtain

Square meters $\left(\mathrm{m}^{2}\right)$ Cubic hectometers $\left(\mathrm{hm}^{3}\right)$

Cubic hectometers $\left(\mathrm{hm}^{3}\right)$

Meters ( $m$ )

Meters per day $(\mathrm{m} / \mathrm{d})$

Liters (L)

Liters per second (L/s)

Millimeters (mm)

Kilometers $(\mathrm{km})$

Square kilometers $\left(\mathrm{km}^{2}\right)$

\section{ALTITUDE DATUM}

The term "National Geodetic Vertical Datum of 1929" replaces the formerly used term "mean sea level" to describe the datum for altitude measurements. The datum is derived from a general adjustment of the first-order leveling networks of both the United States and Canada. For convenience in this report, the datum is referred to as "sea level." 


\author{
WATER-RESOURCES APPRAISAL OF THE \\ GALENA CREEK BASIN, WASHOE COUNTY, NEVADA
}

By Terry Katzer, Timothy J. Durbin, and Douglas K. Maurer

\begin{abstract}
Hydrologic and geophysical data to evaluate the water resources of the Galena Creek basin were collected during the spring and summer of 1979 . The analysis showed that precipitation on the basin averages about 32,000 acre-feet of water per year, but about 22,000 acre-feet per year is lost to the atmosphere through primary evapotranspiration. The remainder, about 10,000 acre-feet per year, constitutes the available water resource for the Galena Creek ground-water basin, and is represented as inflow or outflow, as follows: Surface-water inflow to the basin averages about 8,100 acre-feet per year and ground-water inflow averages about 1,900 acre-feet per year. Surface-water outflow from the basin averages about 4,700 acre-feet per year and ground-water outflow averages about 4,400 acre-feet per year. Additionally, about 940 acre-feet per year leaves the ground-water basin as secondary evapotranspiration of applied irrigation water and domestic pumpage.
\end{abstract}

A preliminary two-dimensional steady-state ground-water model was developed for the basin to estimate roughly the quantities and locations of ground-water leaving the basin.

\title{
INTRODUCTION
}

\section{Purpose and Scope}

The 18-square-mile Galena Creek basin in the southern part of Washoe County, Nev., was mostly rural in character until about 1970. Since then, it has experienced rapid residential development for which the water supply depends entirely upon resources within the basin. Though an earlier reconnaissance level water-resources appraisal provided some information on the available supply (Van Denburgh and others, 1973), the Nevada Division of Water Resources asked the U.S. Geological Survey to make a more detailed appraisal of the surface-water and ground-water inflows to the basin and the respective outflows from the basin.

The scope of the requested appraisal was to develop water budgets for the Galena Creek drainage basin and the Galena Creek ground-water basin. Owing to a lack of hydrologic data on ground-water outflow from the basin, a reconnaissance ground-water model was developed to estimate the direction and magnitude of those values. 


\section{Significance of Numerical Values}

Some numerical values in this report are expressed with more significant figures than would be indicated by the actual reliability of the numbers. This usually results from aggregation of water-budget items, and its purpose is to preserve a mathematical consistency in the water budget. Therefore, the reader is cautioned that most of the numerical values in this report are considered reliable to one or at most two significant figures.

\section{Availability of Data}

Ground-water data collected for this investigation have been placed in the Geological Survey's WATSTORE (Water Data Storage and Retrieval) System; site-inventory data have been entered for about 70 wells and include about 100 measurements of ground-water levels. Additionally, about 70 measurements of stream discharge at 9 surface-water sites will be published by the U.S. Geological Survey (in press).

\section{Acknowledgments}

The authors are indebted to the many home owners who allowed their wells to be measured, and in particular to members of the Galena Creek Home Owners Association, who made their past water-level measurements available. Special thanks go to Harry and Viola Callahan, who allowed access to their land.

Acknowledgment is also given to the many persons of the U.S. Geological Survey who contributed to the study. Susan Mathews, Nyle Pennington, Paul Manoukian, and Kenneth Pringle participated in the field work, and many others contributed indirectly to the study and this report.

\section{Numbering System for Hydrologic Sites}

The numbering system for hydrologic sites in this report indicates location on the basis of the rectangular subdivision of public lands, referenced to the Mount Diablo base line and meridian. Each number consists of three units: The first is the township north of the base line; the second unit, separated from the first by a slant, is the range east of the meridian; the third unit, separated from the second by a dash, designates the squaremile section. The section number is followed by letters that indicate the quarter section, quarter-quarter section, and so on; the letters A, B, C, and $D$ designate the northeast, northwest, southwest, and southeast quarters, respectively. The letters are followed by a sequence number. As an example of the application of the numbering system, well N17 El9 02ACBDl is located within a $2 \frac{1}{2}$-acre tract identified as SE $\frac{1}{4}+$ SW $\$$ NEt sec. 2, T. 17 N., R. 19 E., and it is the first we 11 recorded in that tract. 
Location and Physiographic Setting

The Galena Creek basin, which is a subarea of the Truckee Meadows hydrographic area (Rush, 1968), is in Washoe County about 10 miles south of Reno. The basin is about 8 miles long, west to east, and 2 miles wide, with an area of 18.0 square miles (figure 1 ).

The Galena Creek basin includes steep mountain slopes of the Carson Range and the Steamboat Hills, and associated, but less steep, alluvial fans. The Carson Range separates the basin from the Lake Tahoe basin immediately to the southwest. Within the study area, the crest of the Carson Range has an altitude of almost 10,800 feet above sea leve1. The Steamboat Hills separate the basin from Pleasant Valley immediately to the east, and they reach a maximum altitude of about 6,000 feet. The alluvial fans slope downward from the Carson Range toward the Steamboat Hills, and range in altitude from 6,500 to 5,000 feet.

The overall study area includes the drainage basin of Galena Creek upstream from the point where it enters the gorge that cuts across the southern tip of the Steamboat Hills. Within this drainage basin, the mountain slopes constitute an area of 11.6 square miles, and the alluvial fans constitute an area of 6.4 square miles.

References are made in this report to the Galena Creek drainage basin and the Galena Creek ground-water basin. The drainage basin comprises both the mountain slopes and alluvial fans, but the ground-water basin is generally coincident with the area of alluvial fans within the drainage basin, thereby constituting only about a third or 5.54 square miles of the overall study area (figure 2).

\section{Hydrogeologic Setting}

General Lithologic and Water-Bearing

Character of Geologic Units

On the basis of their relative capacity to store and yield ground water, the rocks and deposits of the Galena Creek basin are divided into two classes. First are the consolidated rocks, which yield water only from fractures--in such sma11 quantities that the development of high-yield wells in these rocks is not ordinarily feasible. Second are the unconsolidated deposits, which have connected interstices that yield appreciable quantities of water to we 11 s.

Consolidated rocks.--The consolidated rocks, which are exposed in the Carson Range and the Steamboat Hills (figure 3), include granodiorite, metamorphic, and volcanic rocks (Tabor and E1len, 1975, and Thompson and White, 1964). Metasedimentary and metavolcanic rocks crop out in the Steamboat Hills and locally in the Carson Range. Intrusive igneous rocks that range in type from granodiorite to quartz monzonite dominate in the Carson Range. Only slightly less abundant there, however, are exposures of volcanic rocks. Volcanics are the principal rocks of the Steamboat Hills. 


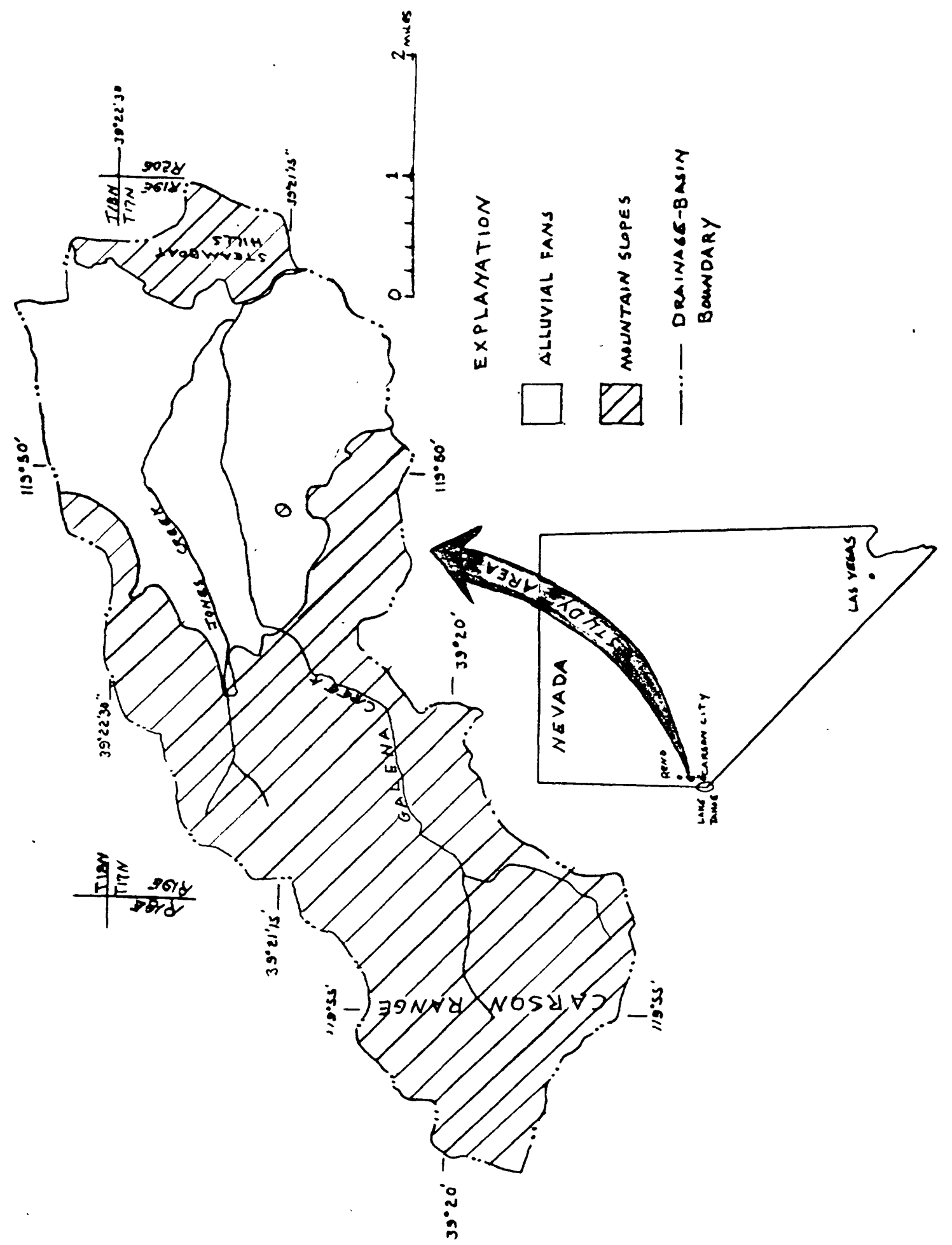

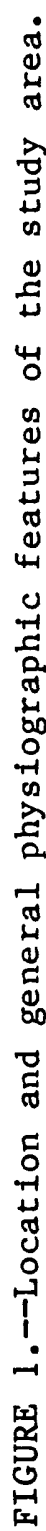




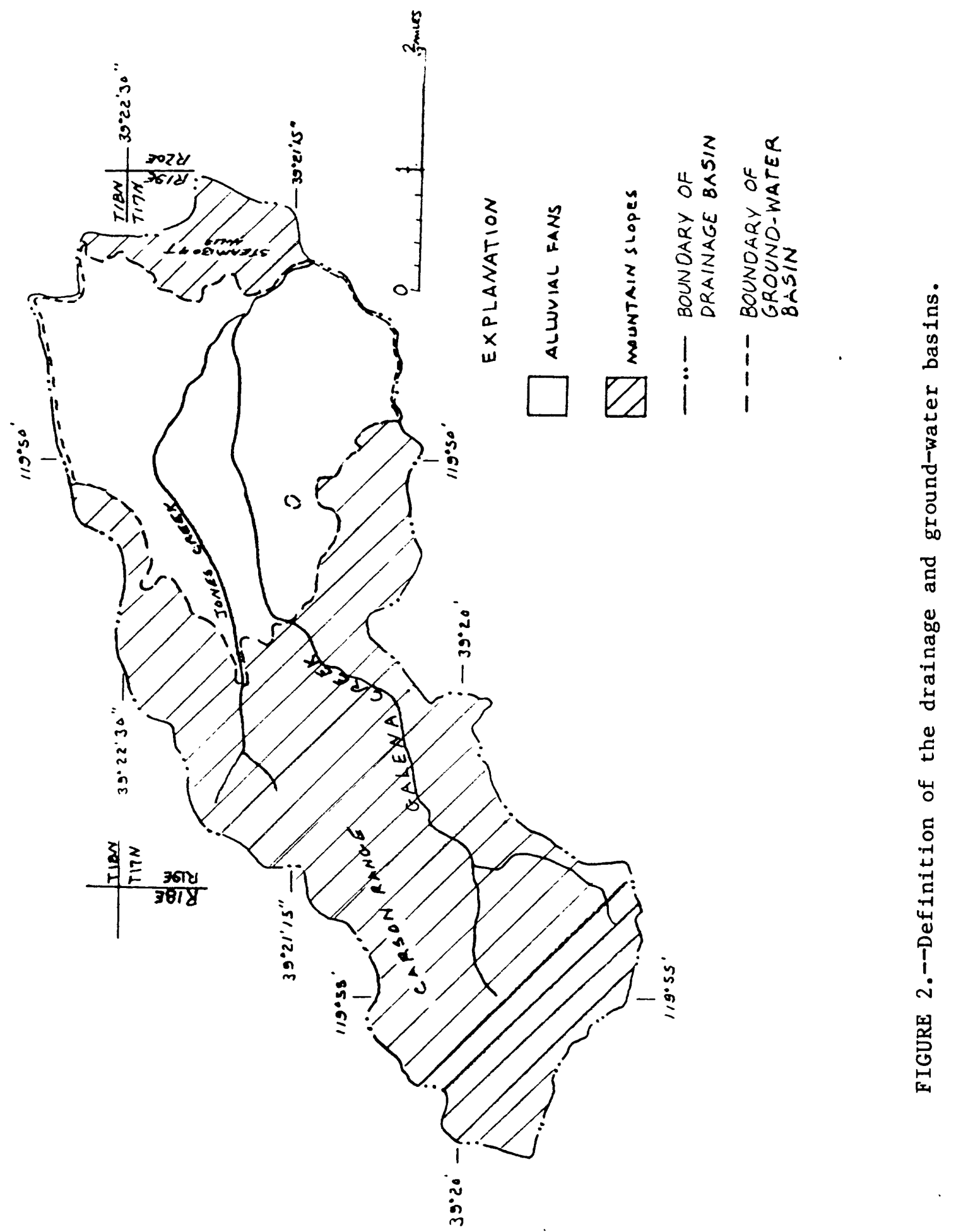




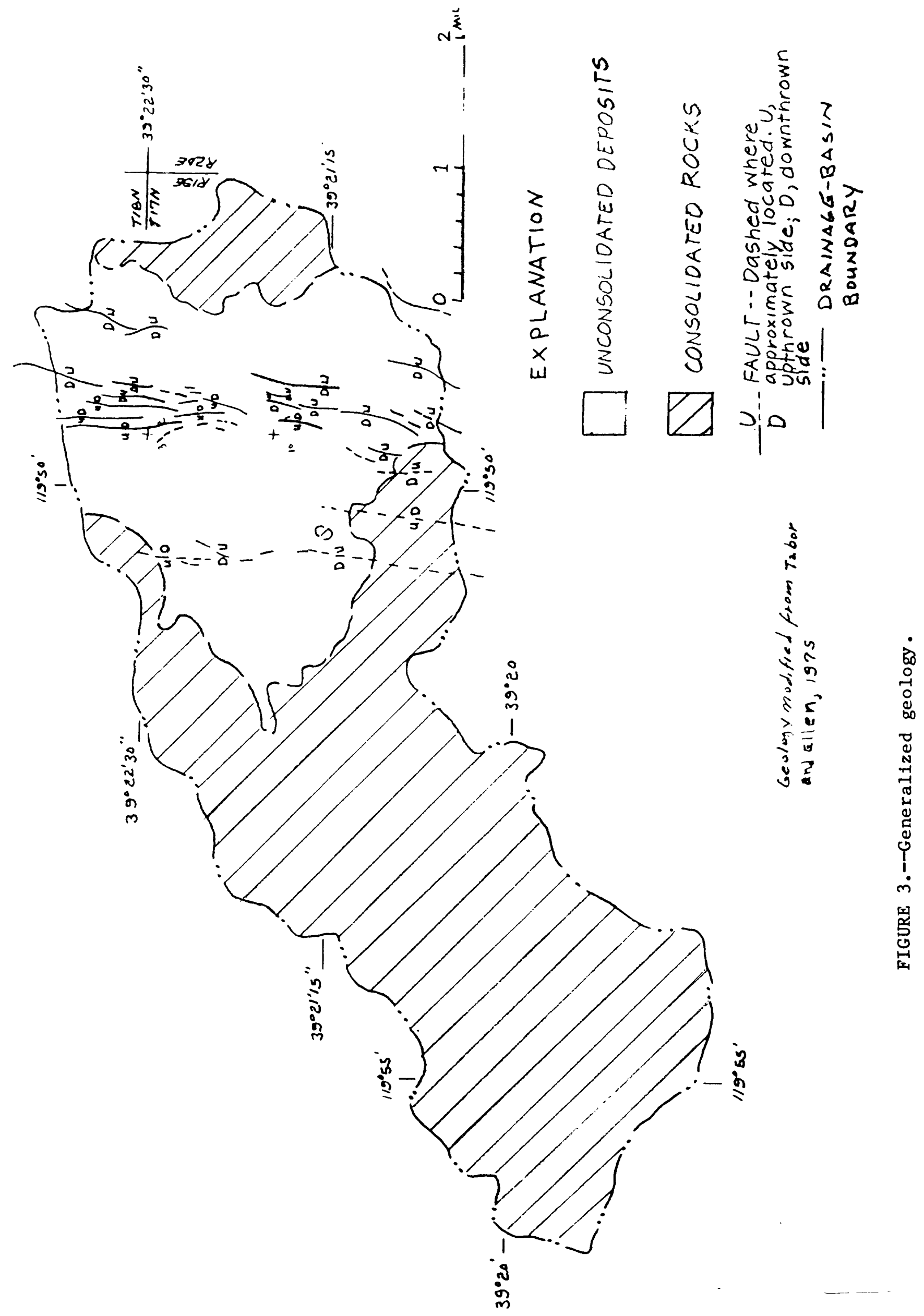


Little information is available on the water-bearing character of the consolidated rocks. The metamorphic and igneous rocks probably contain little water except locally along joints and faults which are not considered significant to the movement of ground water in the basin. The volcanic rocks, however, may contain a sufficient density and interconnected network of fractures that provide conduits for the movement of ground water in the basin. For example, Desormier (1983) describes a geothermal production well that has a flow rate of 1,250 gallons per minute and is 3,050 feet deep near the east side of the Steamboat Hills. Ground-water gradients in the unconsolidated deposits of the study area, however, do not suggest a significant regional movement of ground water into the Steamboat Hills. Ground water discharges from the Galena Creek basin primarily through the alluvium northwest of the Steamboat Hills and as surface water and ground water in and beneath Galena Creek where the creek enters the Steamboat Hills. Minor springs and seeps in the Steamboat Hills probably are fed by ground-water inflow from the Galena Creek basin and local ground-water recharge from precipitation on the Steamboat Hills.

Unconsolidated deposits.--The unconsolidated sedimentary deposits, which are exposed principally on the alluvial fans between the Carson Range and the Steamboat Hills (figure 3), include alluvial and glacial deposits as mapped by Tabor and Ellen (1975). Alluvial sediments are the predominant form of unconsolidated deposits in the study area. They underlie all of the area between the Carson Range and the Steamboat Hills. These deposits are characterized by a very coarse bouldery gravel (boulders as much as 12 feet in diameter) in the first 100 feet below land surface, and by silt, sand, and fine gravel at greater depth. The glacial deposits are found in the canyon bottoms of the Carson Range.

Most wells that penetrate the unconsolidated deposits are not much more than 200 feet deep, and data from these wells therefore provide information mostly on the shallow, very coarse-grained interval. These data indicate that, on the basis of specific capacities, the hydraulic conductivity in the shallow interval averages about 2 feet per day. The specific capacities of wells range from 0.1 to 12 gallons per minute per foot of drawdown (figure 4), and are based on drawdown and pumping rates as reported by well drillers. A preliminary ground-water model, described later in this report, indicates that the average hydraulic conductivity of the deep, fine-grained interval of unconsolidated deposits may also be about 2 feet per day.

\section{General Structural Features}

The Galena Creek basin is a fault-controlled depression between the Carson Range and the Steamboat Hills (figure 5). Displacements along northward-trending normal faults in the Carson Range mountain block stairstep downward to the east. Similarly, displacements in the Steamboat Hills mountain block stair-step downward to the west. The result is a structural depression with a cumulative displacement of about 8,000 feet on the west and about 2,000 feet on the east. 


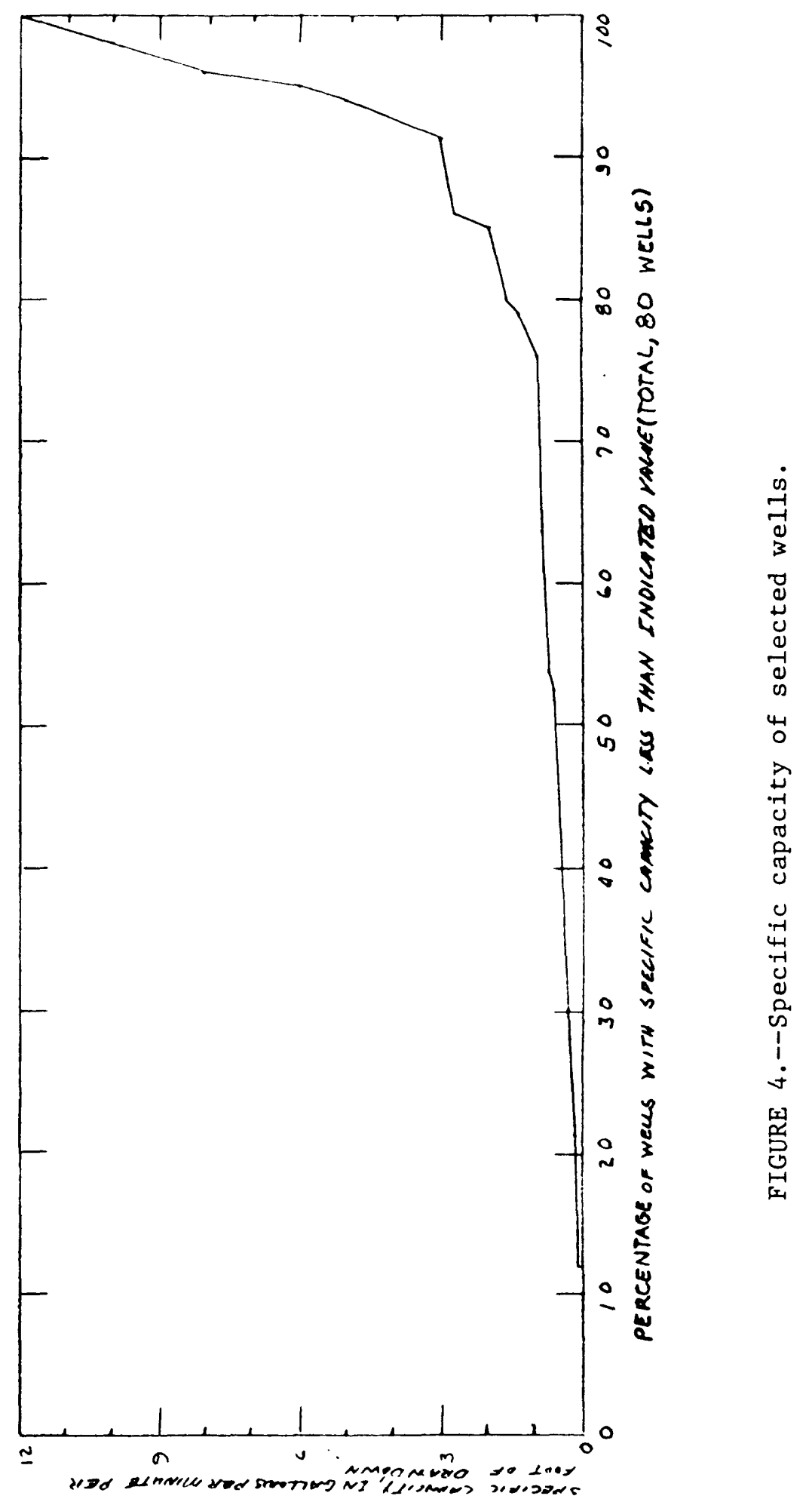

$-8-$ 


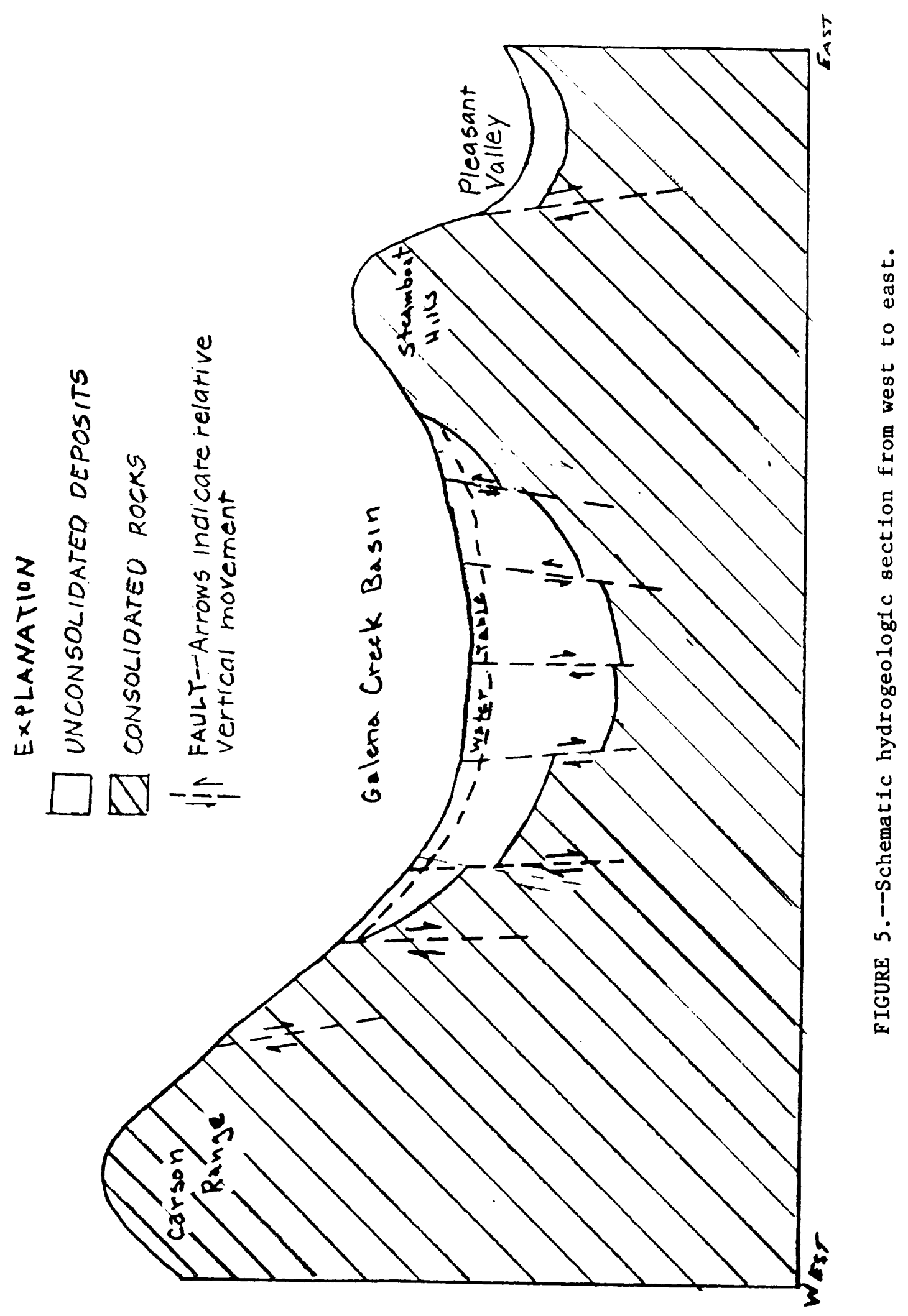


A series of north-trending subparallel faults have also displaced the unconsolidated deposits that in part fill the structural depression between the Carson Range and the Steamboat Hills (figure 3). Surface displacements of more than 20 feet can be observed in parts of the study area. The faulting, which affects local ground-water levels across the faults up to about 40 feet, does not appear to greatly affect the regional movement of ground water through the unconsolidated deposits.

\section{Thickness of Unconsolidated Deposits}

Unconsolidated deposits fill the Galena Creek basin to an estimated maximum thickness of about 1,000 feet, as determined by a gravity survey. Figure 6 shows that the thicker deposits generally are found near the northcentral part of the basin. In the south-central part unconsolidated deposits are generally less than 200 feet thick.

Gravity measurements.--A gravity survey was used to estimate the thickness of unconsolidated deposits in the study area. The intensity of the earth's gravitational field is different from place to place, depending in part on variations in the density of subsurface materials. In general, the intensity of the gravitational field is lower over areas underlain by lowerdensity materials (such as unconsolidated deposits) than over areas underlain by higher-density materials (such as igneous rocks). The thickness of lowerdensity materials that overlie higher-density materials can be estimated from field gravity measurements.

During this study, gravity readings were made at 55 stations in the Galena Creek basin using a Worden-type ${ }^{1}$ gravity meter with a scale constant of $0.0965 \mathrm{milligal}$ and scale divisions of $0.1 \mathrm{milliGal}$. A base station, established in the study area, was referenced to a primary base station in Carson City (Chapman, 1966, page 49). Gravity readings were taken twice per day at the base station in the study area to provide corrections for instrument drift and tidal effects.

Horizontal and vertical positions of the gravity stations were obtained from a field survey using an electronic distance-measuring transit. Controls for the survey were road intersections for which altitudes are shown on the topographic quadrangle maps (7-1/2'). Consequently, the accuracies of horizontal and vertical positions were limited by the accuracy of the topographic maps, and not by the more accurate relative positioning given by the transit measurements. By use of this method the positions of the stations were obtained to within \pm 100 feet horizontally and \pm 1 foot vertically.

1 Use of brand names in this report is for identification purposes only and does not constitute endorsement by the U.S. Geological Survey. 


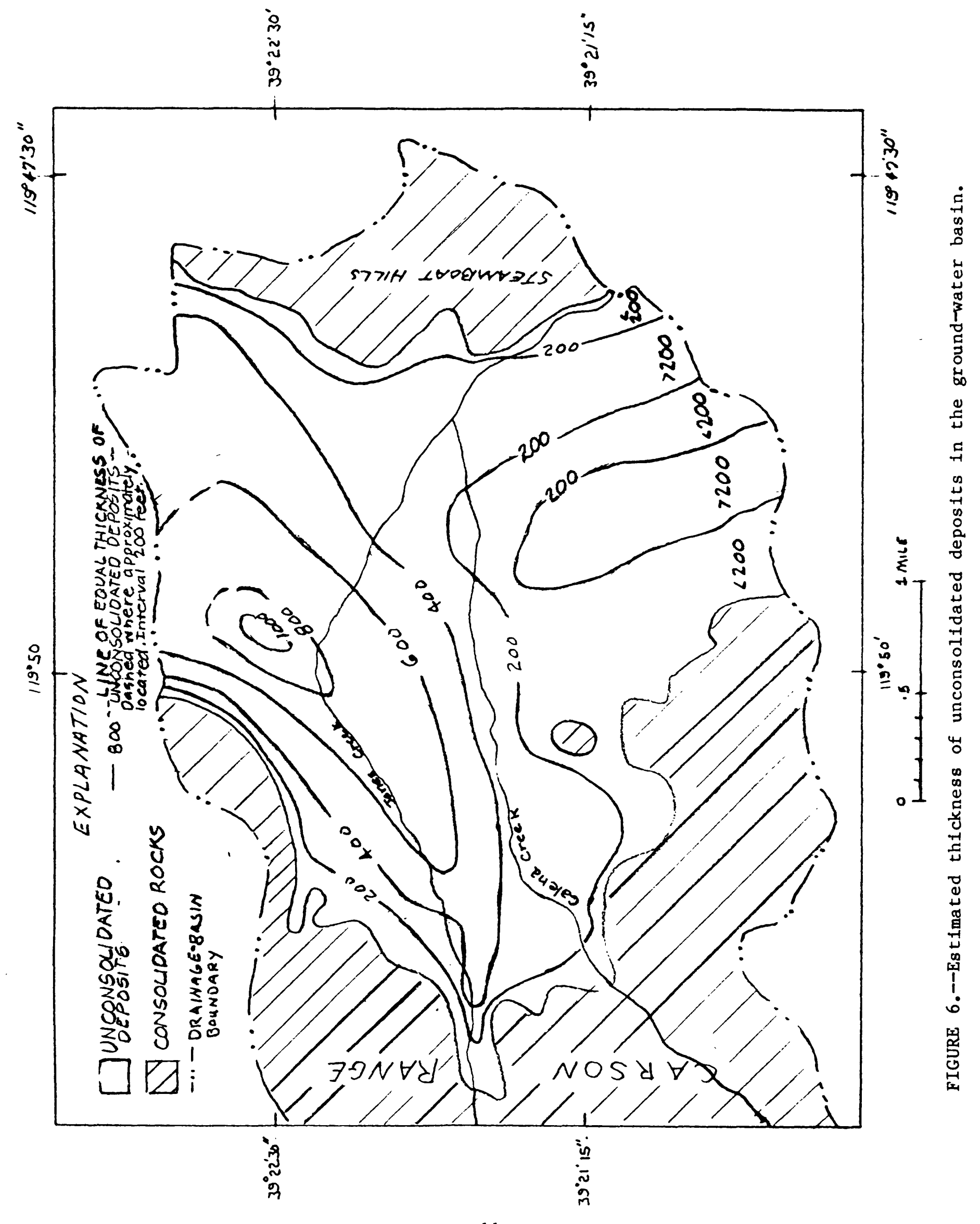


Reduction of gravity data.--Using a computer program developed by Plouff (1977), the gravity readings we re reduced to complete Bouguer gravity anomalies. This program applies corrections to the gravity reading at each station for altitude, latitude, earth curvature, and terrain roughness radially outward from 1.4 miles to 100 miles. Terrain corrections within a radius of 1.4 miles were computed manually using the Hayford-Bowie method (Hayford and Bowie, 1912). The largest total terrain correction was 11 milligals, for a station near the western edge of the study area.

The complete Bouguer gravity anomalies for the study area are shown in figure 7. These anomalies in the intensity of the Earth's gravitational field result from two additive effects: gross regional variations in the thickness and density of the Earth's crust, and local variations in the density of subsurface materials such as unconsolidated deposits in the Galena Creek basin. By subtracting the regional effects from the Bouguer anomalies, the local effect, or gravity residual, can be obtained.

The residual gravity anomalies, which are shown in figure 8 , were determined in part by contouring regional anomalies, using data for gravity stations on bedrock. The regional map was then used to estimate the value of the regional anomaly at each gravity station. These values were subtracted from the complete Bouguer anomalies to obtain the residual anomalies. Finally, the residual gravity anomalies were contoured as shown in figure 8 .

Interpretation of gravity data.--Using a computer program developed by Crewdson (1976), the thickness of unconsolidated deposits (figure 6) was calculated from the residual gravity anomaly. A density contrast of 0.73 gram per cubic centimeter between the consolidated rocks and unconsolidated deposits was used in the calculations. This density contrast produced a calculated thickness of unconsolidated deposits that agreed closely with the results of a seismic refraction sounding (Tabor and Ellen, 1975) within a deeper part of the basin. This seismic method determines the vertical depth from the land surface to bedrock by measuring the travel times of elastic waves generated at the surface and reflected back to the surface from the bed rock.

\section{Hydrologic Setting}

\section{Source of Water}

The source of all water in the Galena Creek basin is precipitation. Most of the precipitation results from regional frontal systems that move into Nevada from the north Pacific Ocean during the winter months. Additionally, some precipitation results from frontal systems that originate from the south, typically during the summer and fall. On the average, the Pacific and southern storms together deposit about 65 inches of precipitation on the crest of the Carson Range and about 15 inches at the point of lowest altitude in the study area. 


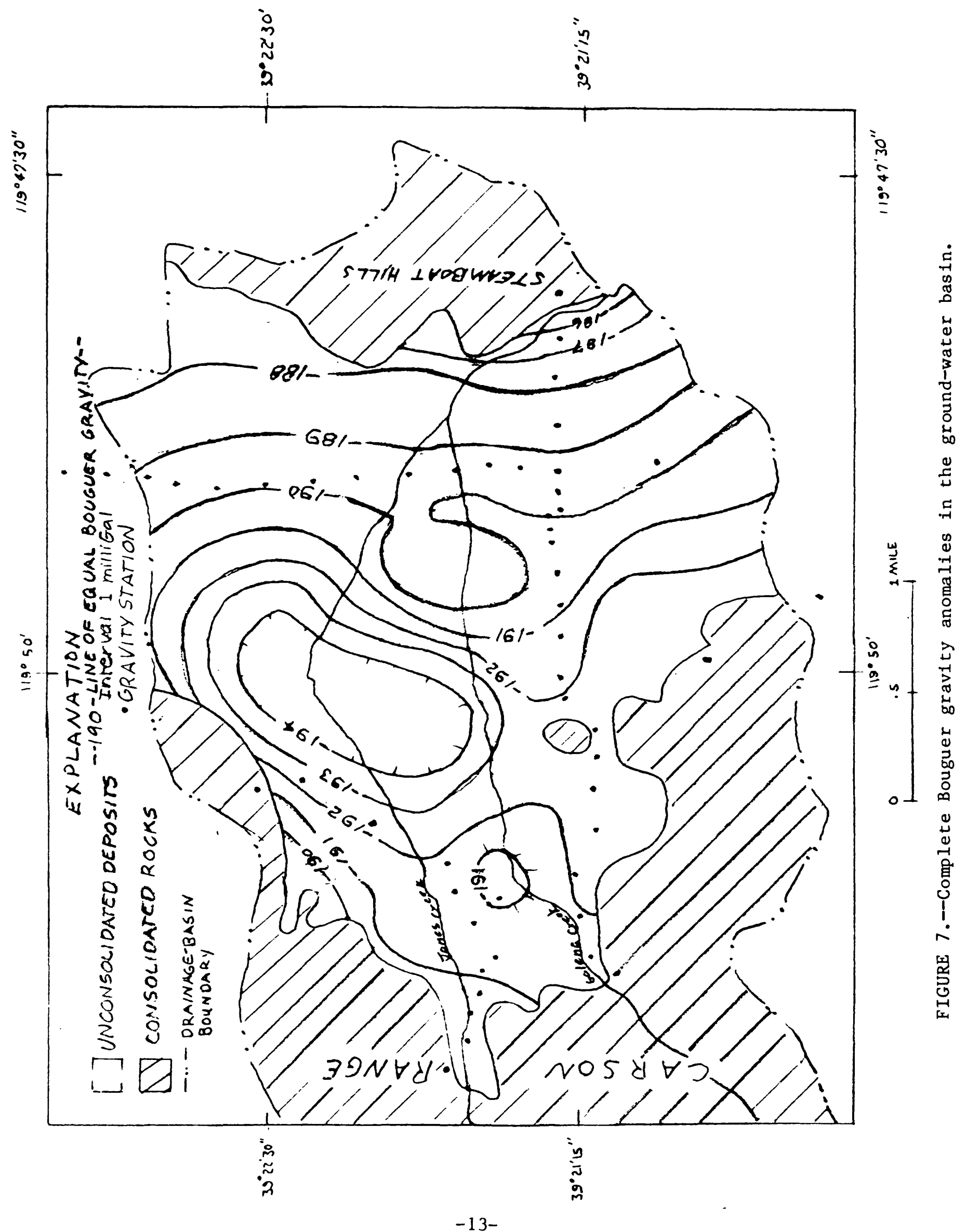




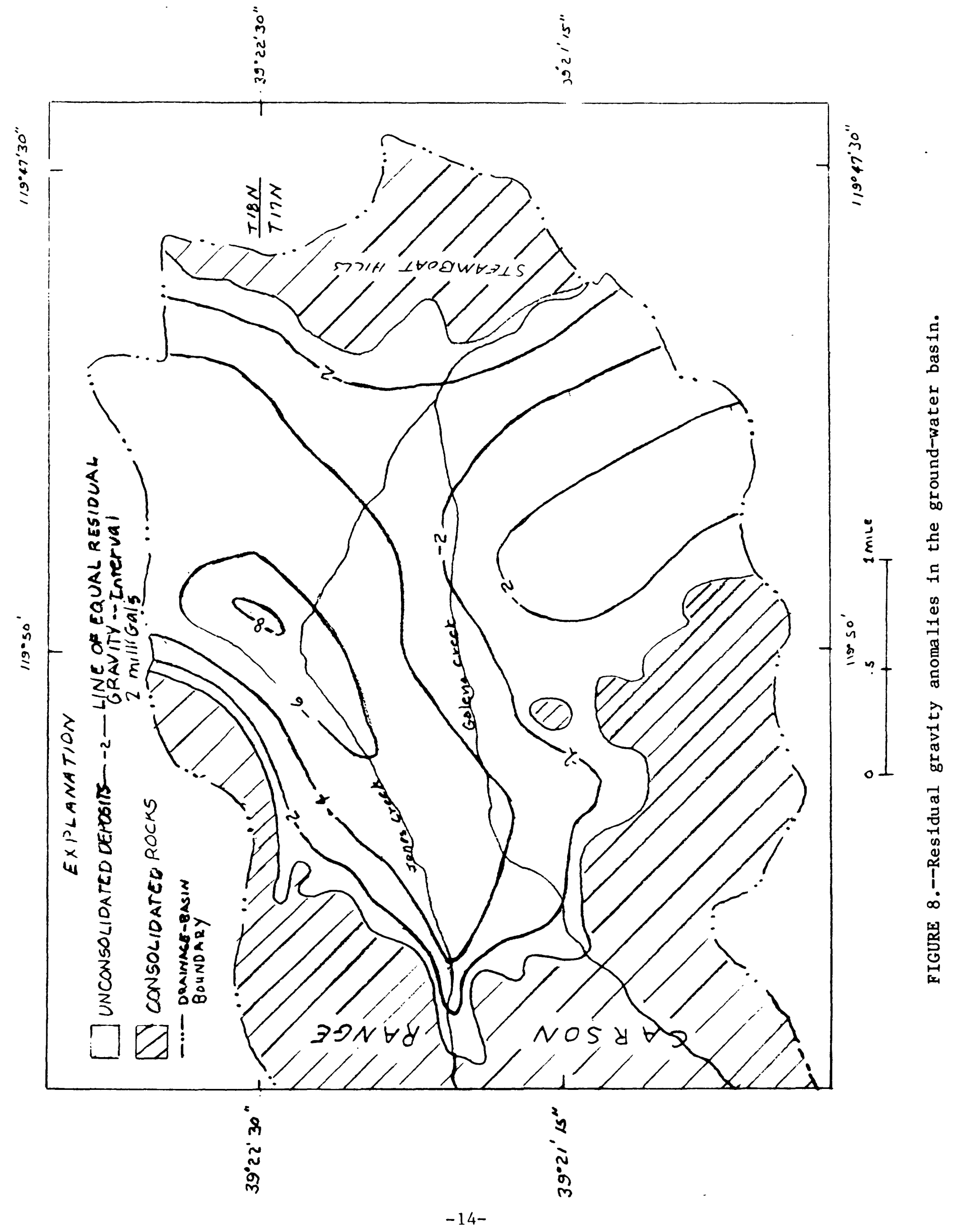


of the precipitation that falls on the basin, part is lost by primary evaporation and transpiration, part contributes to streamflow, and part recharges the ground-water basin. As is discussed in more detail later, the area-averaged mean annual precipitation on the study area is about 33 inches, or about 32,000 acre-feet. Of this precipitation, about 23 inches, or about 22,000 acre-ft/yr is evaporated from the soil or transpired by native vegetation, and is defined as primary evapotranspiration in contrast to secondary evapotranspiration which is the consumption of water by applied irrigation and urban use. The remainder becomes either ground-water recharge or streamflow. This residual, which averages about 10 inches, or about $10,000 \mathrm{acre-feet/yr,}$ constitutes the average annual surface-water and ground-water inflow to the Galena Creek basin.

\section{Ground-Water Levels}

Water in the Galena Creek ground-water basin moves from major areas of recharge toward areas of ground-water and surface-water discharge. As shown in figure 9, part of the ground water moves from recharge areas in the western part of the basin toward the north and northeast, where it leaves the ground-water basin. Another part of the ground water moves from the recharge areas toward the east, where it also discharges from the ground-water basin. Figures 9 and 10 show depths to water and the water-surface altitude, respectively, in the spring of 1979. Water-level altitudes ranged from 6,100 to 5,500 feet in the western part of the basin, from 5,700 to 5,400 feet along the northern boundary of the basin, and were less than 5,300 feet near where Galena Creek crosses the eastern boundary of the basin.

Sources of data.--Two sources of information were used to determine the depth-to-water ranges shown in figure 9 and the water-level contours shown in figure 10. Depths to water were measured at about 70 wells in the study area (table 7). To supplement the well data, vertical electrical resistivity soundings were made at 13 sites to estimate the depth to ground water. The location of these wells and resistivity stations is shown in figure 11 . Land-surface altitudes at the wells and resistivity stations we re estimated using 7.5-minute topographic quadrangle maps, and these estimates were then used in combination with the depth-to-water data to calculate water-surface altitudes.

Vertical electmical soundings.--Thirteen vertical electrical resistivity soundings were'made in the study area (figure 11) to estimate the depth to the water table. By this procedure, an electrical current is passed through the subsurface materials, and the resulting voltage drop is measured to calculate the variations in resistivity with depth. This technique can be used to locate the water table because saturated materials generally have a lower resistivity than unsaturated materials.

A Schlumberger-type electrode configuration was used for the soundings; it is described in detail by Zohdy and others (1974). The electric current is applied by the use of two outer electrodes that are moved stepwise away from a center point, which gradually increases the depth of penetration of the electric current. The resulting voltage drop is read from a pair of inner electrodes. The maximum spacing was 2,000 feet for the outer electrodes and 200 feet for the inner electrodes. 

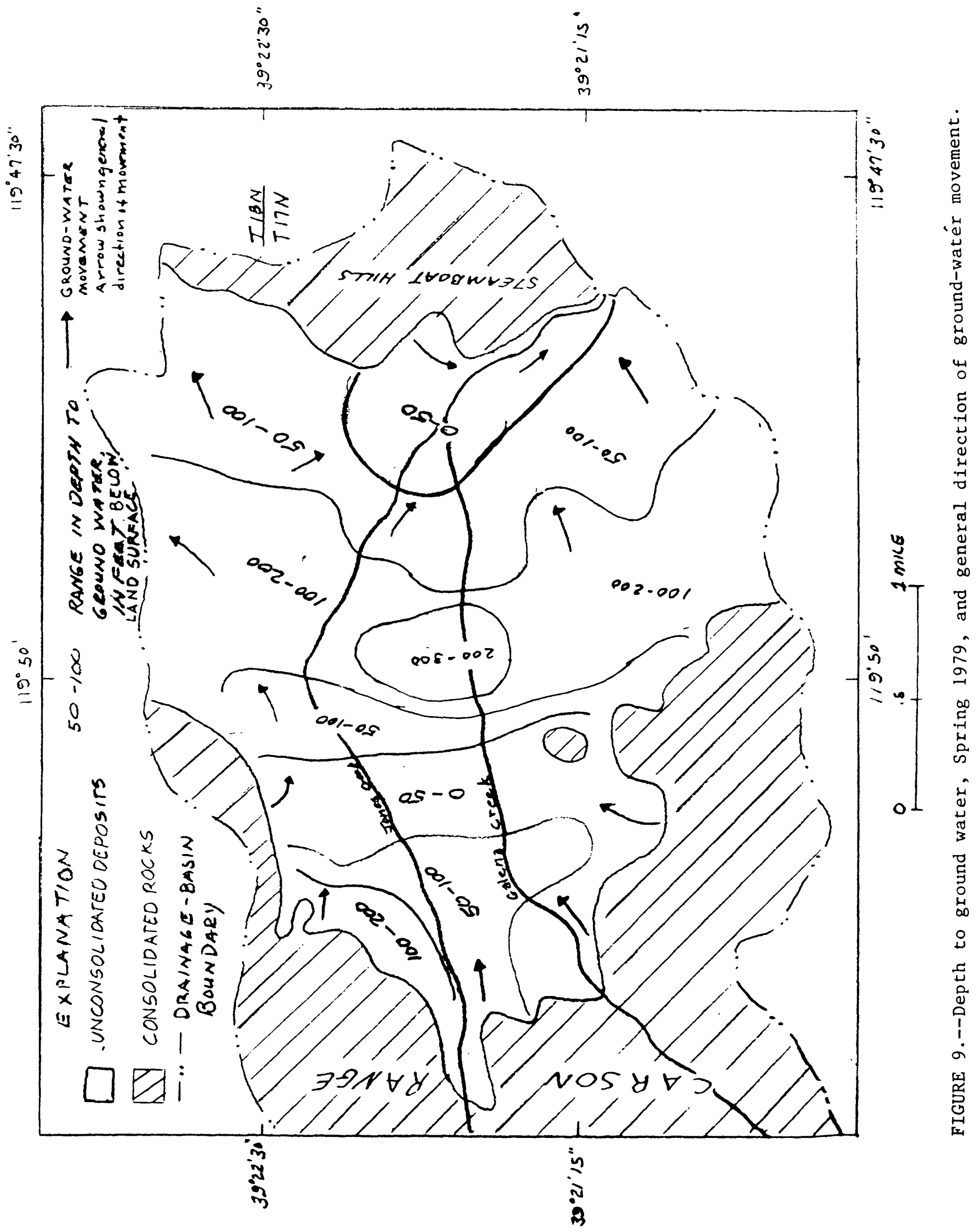


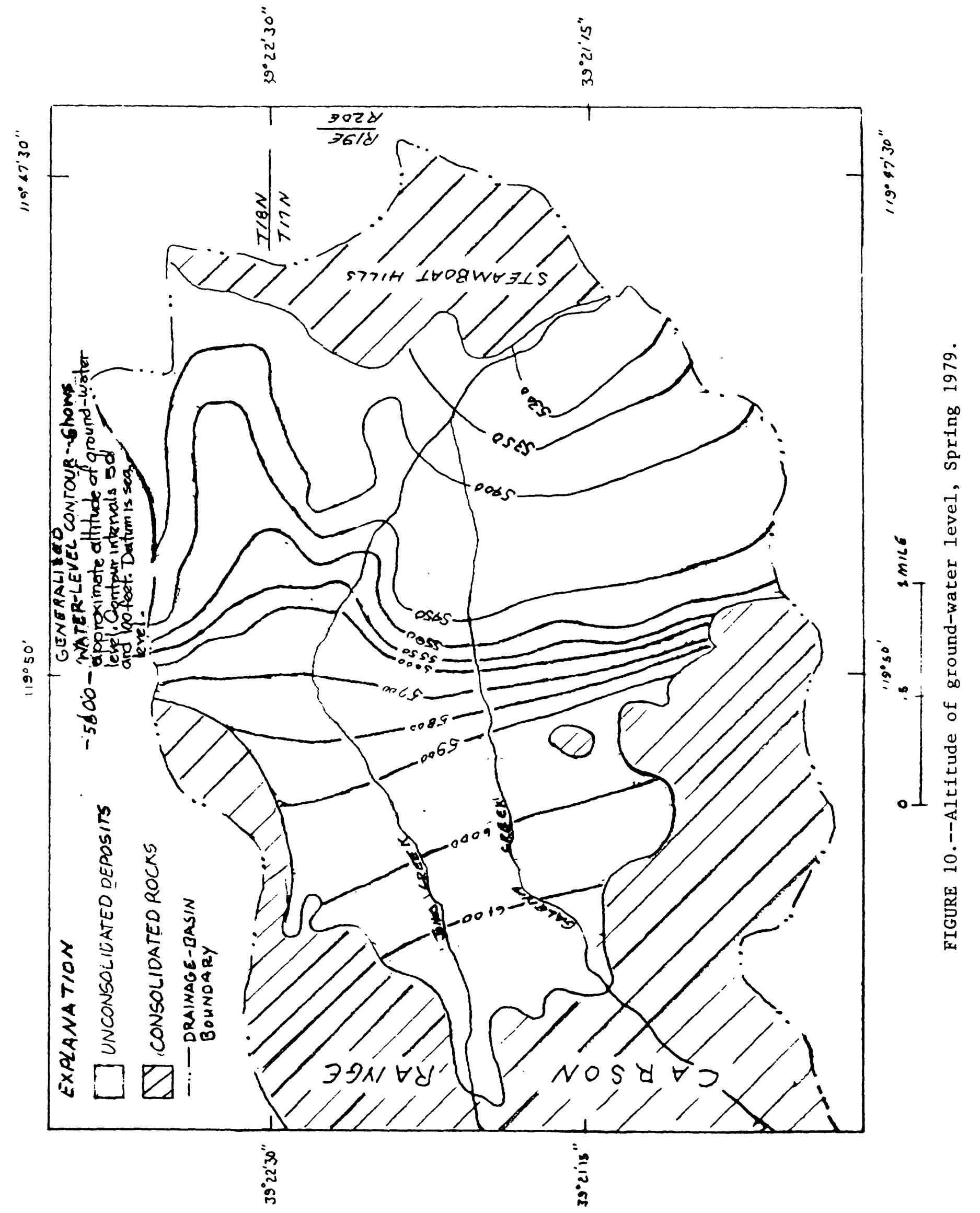




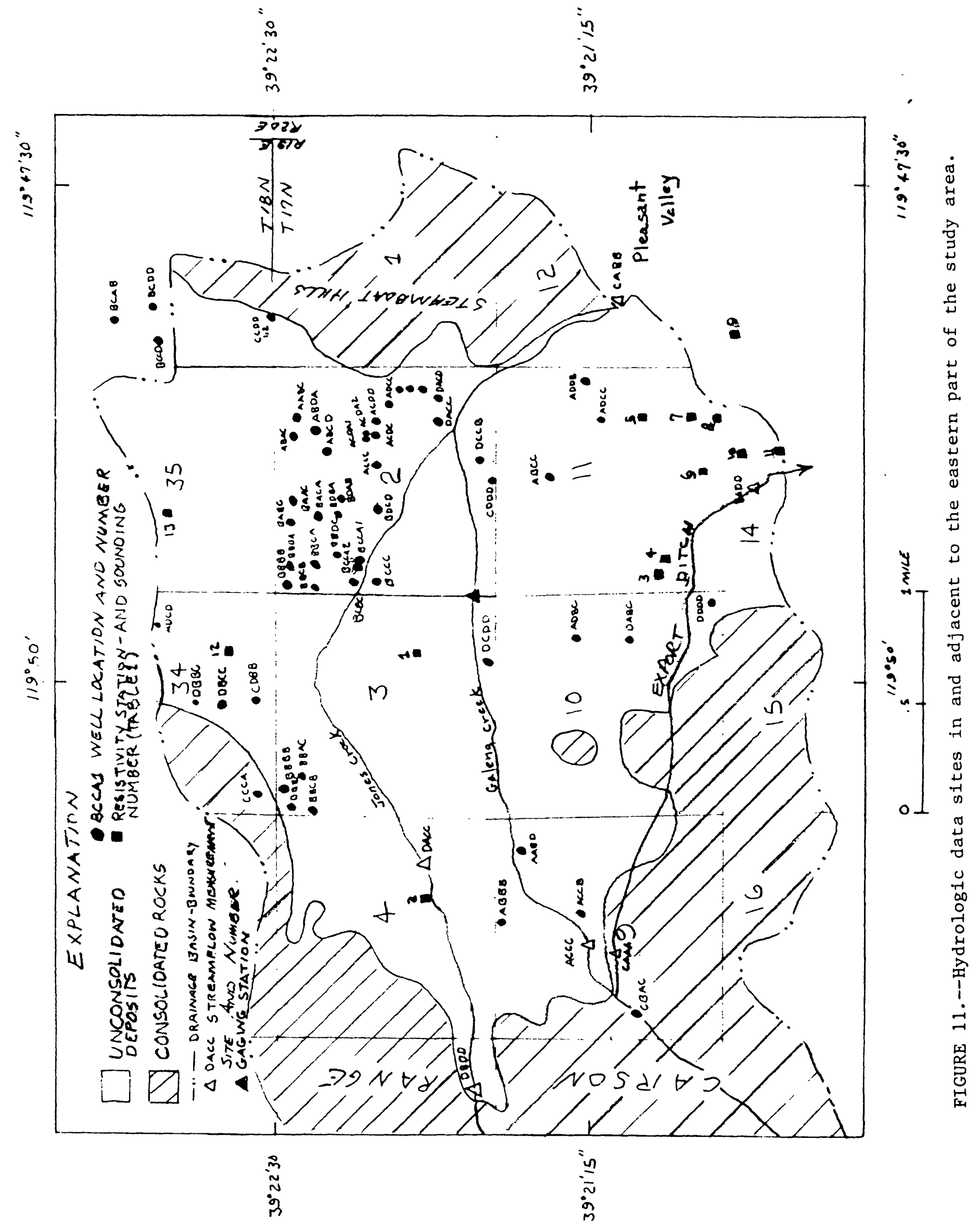


Table 1 gives the calculated water-table depth and the resistivity of saturated deposits below the water table for each of the soundings.

Resistivities above the water table characteristically ranged from 600 to $200 \mathrm{ohm}$-meters, with thin individual layers having resistivities of less than 100 ohm-meters (these thin layers were assumed to be fine-grained deposits). The interface below which resistivities were about $170 \mathrm{ohm}$-meters or less for large thickness was interpreted as the water table. The value of $170 \mathrm{ohm}-$ meters was chosen on the basis of work by Zohdy and others (1974) in the southwestern United States.

$$
\begin{aligned}
& \text { Ground-Water Recharge, } \\
& \text { Storage, and Discharge }
\end{aligned}
$$

Recharge to the Galena Creek ground-water basin occurs mostly in the western part (figure 23), because of the greater availability of water resulting from precipitation on the eastern slope of the Carson Range. Some of this precipitation infiltrates the soil mantle and eventually percolates downward to the ground-water table. Additionally, precipitation that becomes streamflow may in part infiltrate the channel bed and also eventually percolate downward to the water table.

Ground-water recharge has created a reservoir of stored water within the unconsolidated deposits of the study area. Assuming an average porosity of 25 percent, an approximate area of 4,000 acres (rounded to nearest thousand acres), and an average saturated thickness of $300 \mathrm{feet}$, the reservoir now (1979) contains about 300,000 acre-feet of water. Not all of this water, however, can be recovered by pumping from the ground-water reservoir. Some of the water, from a practical standpoint, will always remain within the interstices of the deposits. However, for each cubic foot that might be dewatered by 1 owering the water table, about 0.1 cubic foot of ground water could be recovered. Assuming a specific yield of 0.1 and an area of 4,000 acres, about 40,000 acre-feet of water could thus be recovered from the upper $100 \mathrm{feet}$ of saturated material.

Ground water discharges from the Galena Creek ground-water basin in two principal areas (figure 9) defined through the use of a reconnaissance ground-water model are discussed later in the report. Along the northern boundary of the basin, where north and northeastward-moving ground water leaves the basin in the subsurface; and in the southeastern part of the basin, where ground water seeps into the channel of Galena Creek and where a much lesser amount infiltrates into the volcanic rocks of the Steamboat Hills and thereby leaves the ground-water basin. A very minor amount of ground water in the basin is consumed by sparse phreatophytes--plants that obtain much of their water supply in areas where the water table is near the land surface. Willows are the main phreatophytes in the Galena Creek ground-water basin and their consumption of ground water is insignificant. 
TABLE 1.--Depth to water table calculated from soundings of vertical electrical resistivity

\begin{tabular}{|c|c|c|c|c|}
\hline $\begin{array}{l}\text { Sounding } \\
\text { number } \\
\text { (figure 11) }\end{array}$ & \multicolumn{2}{|c|}{ Location } & \multirow{2}{*}{$\begin{array}{c}\begin{array}{c}\text { Resistivity } \\
\text { of saturated } \\
\text { deposits } \\
\text { (ohm-meters) }\end{array} \\
124\end{array}$} & \multirow{2}{*}{$\begin{array}{l}\begin{array}{c}\text { Depth to water } \\
\text { table } \\
\text { (feet below land } \\
\text { surface, rounded) }\end{array} \\
230\end{array}$} \\
\hline 1 & N17 E19 & 03DBAD & & \\
\hline 2 & & 04DBDB & 103 & 100 \\
\hline 3 & & $11 \mathrm{CBCB}$ & 151 & 170 \\
\hline 4 & & $11 \mathrm{CBDB}$ & 90 & 130 \\
\hline 5 & & 11DACE & 142 & 70 \\
\hline 6 & & $11 D C C B$ & 143 & 130 \\
\hline 7 & & $11 D D C C$ & 48 & 80 \\
\hline 8 & & $11 D D C C$ & 183 & 100 \\
\hline 9 & & $13 \mathrm{BBAC}$ & 81 & 80 \\
\hline 10 & & $14 A B B D$ & 136 & 130 \\
\hline 11 & & $14 \mathrm{ACAB}$ & 51 & 90 \\
\hline 12 & N18 El9 & 34DACC & 25 & 260 \\
\hline 13 & & 35BDDD & 167 & 260 \\
\hline
\end{tabular}


The Galena Creek ground-water basin is in a nearly steady-state condition (as of 1979), whereby ground-water recharge approximately equals discharge and the volume of water in storage does not change appreciably with time.

Although recharge does not exactly balance discharge, at any one instant the average recharge over a multiyear period equals the average discharge.

This nearly steady-state situation is illustrated by the water-level hydrograph (figure 12). The hydrograph for we11 N17 E19 02CDDl shows that the water level fluctuates seasonably, and that the longer term trend seems to be slighly downward. There are two probable explanations for this downward trend: (1) the ground-water system has not recovered from the effect of the 1977 drought, and (2) nearby construction of drainage ditches and increased ground-water withdrawals have the resultant effect of lowering the local ground-water table. Thus, for the purposes of this analysis, the ground-water basin is considered to be in a steady state condition.

\section{WATER BUDGET FOR THE DRAINAGE BASIN}

Two water budgets for the Galena Creek study have been developed. The first is for the entire drainage basin and this budget provides the basis for estimating the water budget for the Galena Creek ground-water basin.

\section{The Water-Budget Equation}

The water budget for the Galena Creek drainage basin is simply an accounting of all the water entering and leaving the basin. The only water entering the drainage basin is precipitation. On the other hand, water leaves the basin as evapotranspiration (primary and secondary) and surface- and ground-water outflow. Water entering and leaving the drainage basin is shown schematically in figure 13, and it can be described mathematically by a steady-state water-budget equation in which inflow equals outflow:

$$
P=E+S+G,
$$

where $P=$ precipitation (measured and estimated),

$$
\begin{aligned}
& E=\begin{array}{l}
\text { evapotranspiration (estimated indirectly and includes agriculture } \\
\text { and urban use), }
\end{array} \\
& S=\text { surface-water outflow (measured and estimated), and } \\
& G=\text { ground-water outflow (residual). }
\end{aligned}
$$

The following sections of the report describe the terms of the waterbudget equation in more detail. In summary, table 2 lists the value for each of the terms. 


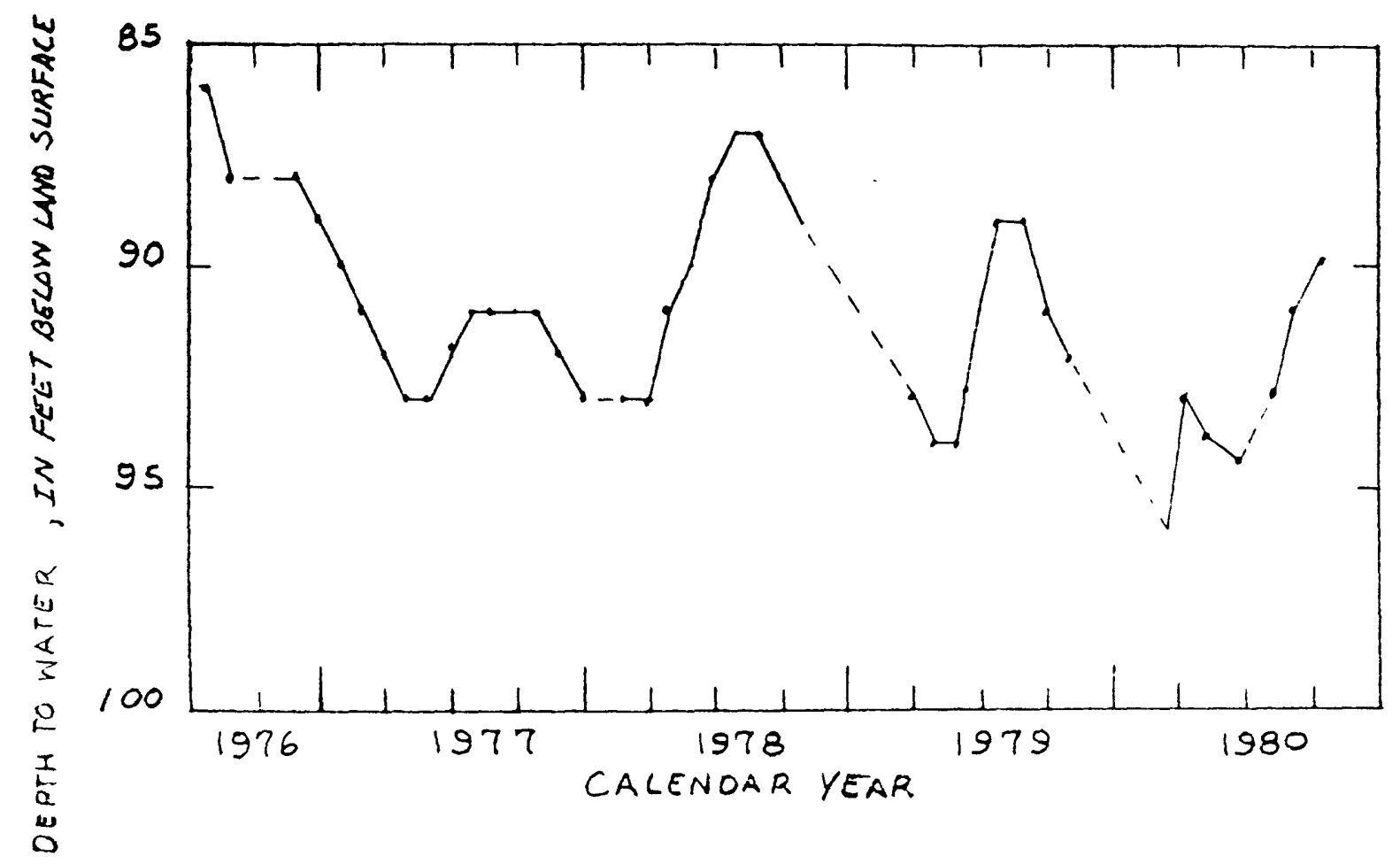

FIGURE 12.--Water-level hydrograph for well N17 E19 02CDDDl. Data points more than about a month apart are connected by dashed line. 

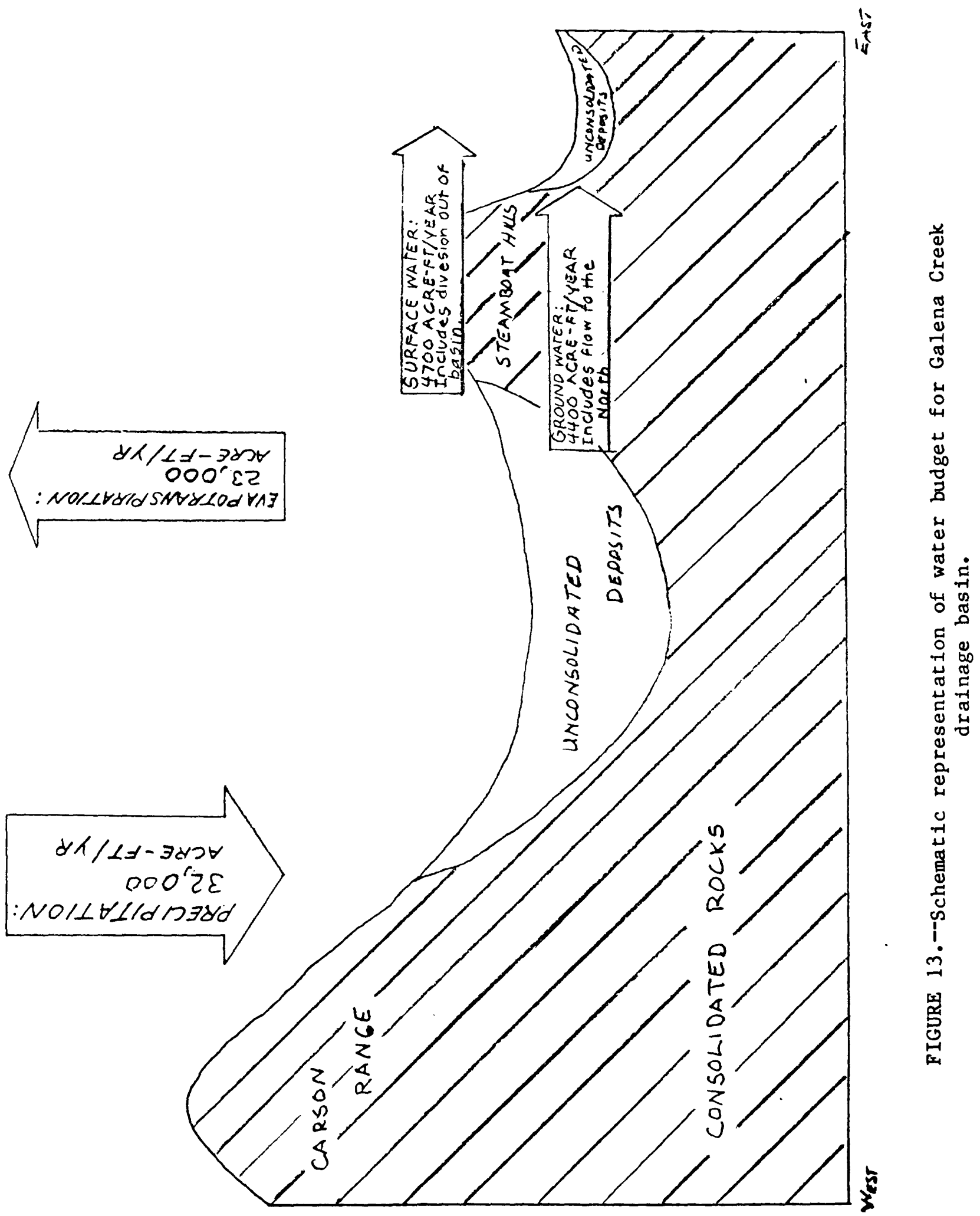
TABLE 2.--Mean annual water budget for the drainage basin 1

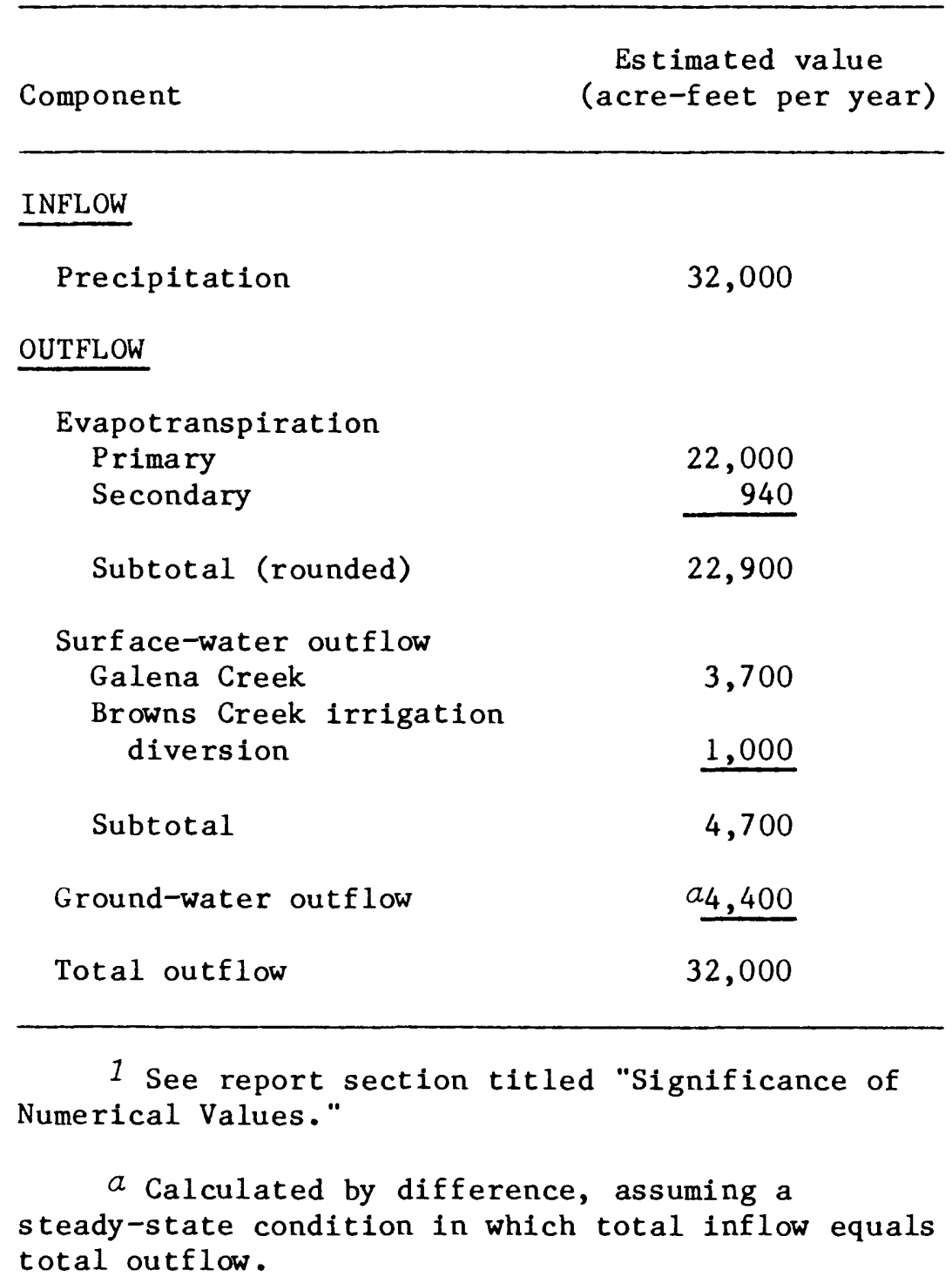




\section{Precipitation}

Precipitation, which is the source of all water in the study area, averages about 32,000 acre-ft/yr for the entire basin. Precipitation in the form of snow provides the most water, although winter and summer rain provides a significant part of the total precipitation in some years. Nevertheless, on the average, snow is the dominant form of precipitation.

\section{Precipitation-Altitude Relation}

Mean annual precipitation is strongly influenced by the orographic effect of the Carson Range--that is, the tendency of precipitation to be greater at higher altitudes on the mountain slopes. This effect is shown in figure 14, which is a plot of mean annual precipitation against altitude for a group of precipitation stations in or near the study area. The least-squares fit of a line through the data points indicates that the mean annual precipitation ranges from about 10 inches at an altitude of 5,000 feet to about 70 inches at about 10,500 feet.

The precipitation data plotted in figure 14 were obtained from Harold E. Klieforth (Desert Research Institute, written communication, 1979). He has operated a network of precipitation stations (approximate locations shown in figure 15) in the study area since 1969. Correlations with data from longterm precipitation stations indicate that the available 10-year record is nearly representative of long-term conditions. Thus, the short term records required only minor adjustment to long-term conditions. No adjustments were made to account for any increase in precipitation resulting from cloud seeding upwind (west) from the study area.

\section{Precipitation Map}

The precipitation-altitude relation in figure 14 was used to prepare a map of the study area showing lines of equal mean annual precipitation. The map was constructed by using the relation to transform a topographic map, which shows contours of equal altitude, into a precipitation map. That map is shown in figure 15 .

The mean annual precipitation volume for the 18-square-mile Galena Creek drainage basin was estimated to be about 32,000 acre-feet.

\section{Evapotranspiration}

Evapotranspiration consumes about 70 percent, or about 23,000 acre-ft/yr, of the precipitation that falls on the Galena Creek drainage basin. Part of that total represents evaporation or transpiration of moisture provided directly by precipitation and is identified as primary evapotranspiration. The remainder (about 900 acre-ft/yr) comprises the evaporation and transpiration of moisture provided by applied irrigation water and urban use and has been previously identified as secondary evapotranspiration. 


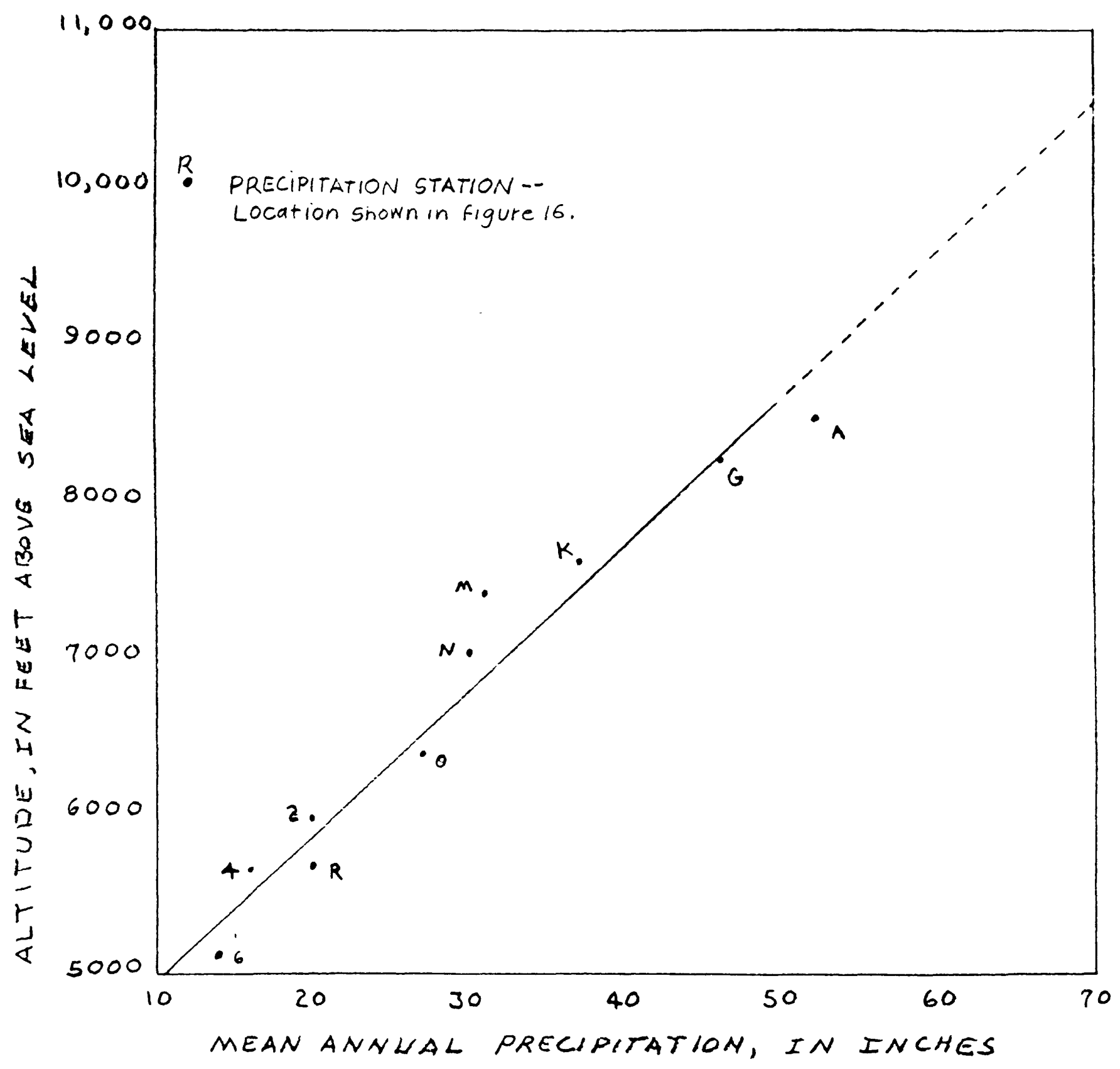

FIGURE 14.--Relation between precipitation and altitude. Data and site designations from H. E. Klieforth (Desert Research Institute, written communication, 1979). 
3

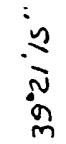

ì

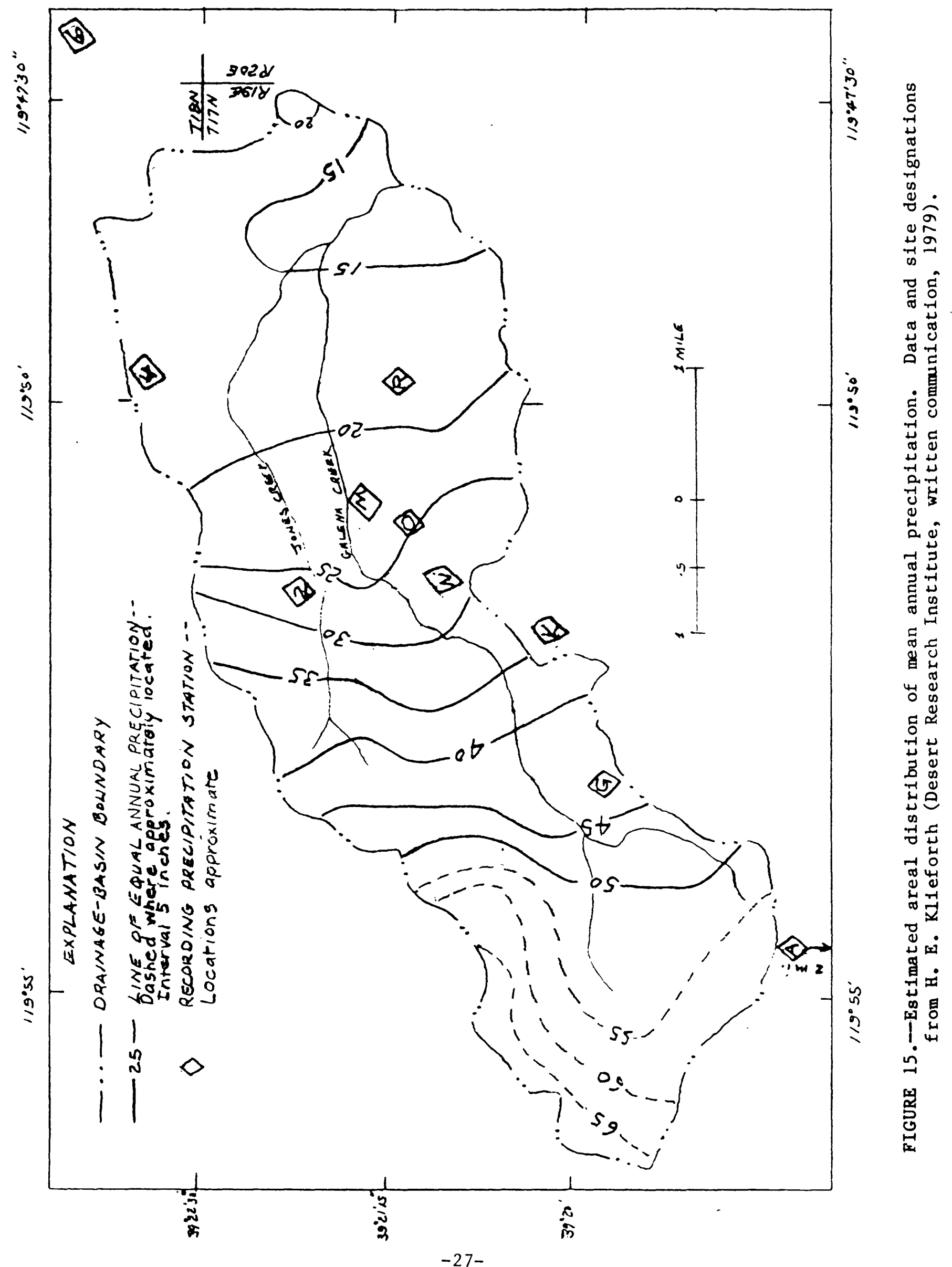


Primary Evapotranspiration

Primary evapotranspiration was estimated by an indirect method. The first step was to develop a relation between mean annual basin precipitation and mean annual surface-water runoff as measured at the bedrock-alluvial contact (which is the component of total precipitation that is not consumed by evapotranspiration and includes the ground-water contribution to surface runoff). Once this relationship was established, then the surface-water runoff was subtracted from the total precipitation, giving evapotranspiration.

Relation between precipitation and moff.--Figure 16 shows the mean annual precipitation-runoff relation for the Galena Creek drainage basin. In the perennial streams used to construct figure 16 the surface flows at the mountain front are represented by (1) direct surface runoff to the channel resulting from rainfall and snowmelt, including springflow, and (2) a groundwater component. Ground water infiltrates through the soil mantle to bedrock, where it flows downgradient until it is intersected by the stream channel and appears as surface flow. Mean annual streamflow data for Daggett, Clear, Hunter, Galena, and Whites Creeks and West Fork Carson River (U.S. Geological Survey, 1963, 1967, and 1980) were used to develop the relation (table 3 ). Also used was the streamflow record for the combined discharge of Kings Canyon and Ash Canyon Creeks (Arteaga and Durbin, 1978, page 22). Data for Galena Creek gaged flows were adjusted to account for losses from upstream irrigation diversions and seepage losses from the mountain front to the gaging station. This adjustment is based on measured and estimated flow diversions and a series of streamflow measurements at the mountain front. The estimated total annual flow represented by the diversions and seepage losses was then added to the gaged record. The estimated, adjusted mean annual flow of Galena Creek at the mountain front equals 8,100 acre-ft/yr.

Streamflow quantities at the sites 1 isted in table 3 were assumed to represent the total water runof $f$ of the drainage basins above the sites. There is a minor amount of ground-water unaccounted for by this technique. At each streamflow gaging station there is generally ground-water underflow that bypasses the station by flowing through the thin, unconsolidated channel deposits between the channel bottom and the underlying bedrock. This amount of water is considered insignificant and is not included in the precipitationrunoff relation. The precipitation-runoff relation was used to estimate runoff from ungaged drainages including ephemeral drainages in the Galena creek basin. The rationale for applying this technique to ephemeral drainages in the Galena Creek basin is that, as a result of precipitation, ground-water flow in excess of soil moisture and evapotranspiration requirements, but insufficient in quantity to appear as surface flow, reaches the basin fill in three ways: (1) Water on the mountain block infiltrates through the soil and percolates downward to the soil-bedrock interface. Most of this water probably follows the interface into the ground-water basin and directly recharges the basin fill, (2) some of the water (an unknown amount) that reaches the bedrock-soil interface probably infiltrates directly into the fractures in the bedrock and may ultimately reach the basin fill or, depending on the fracture system, bypass the basin fill and continue downgradient toward Pleasant Valley and the Truckee Meadows, and (3) water in the alluvial area percolates directly into the basin fill. 


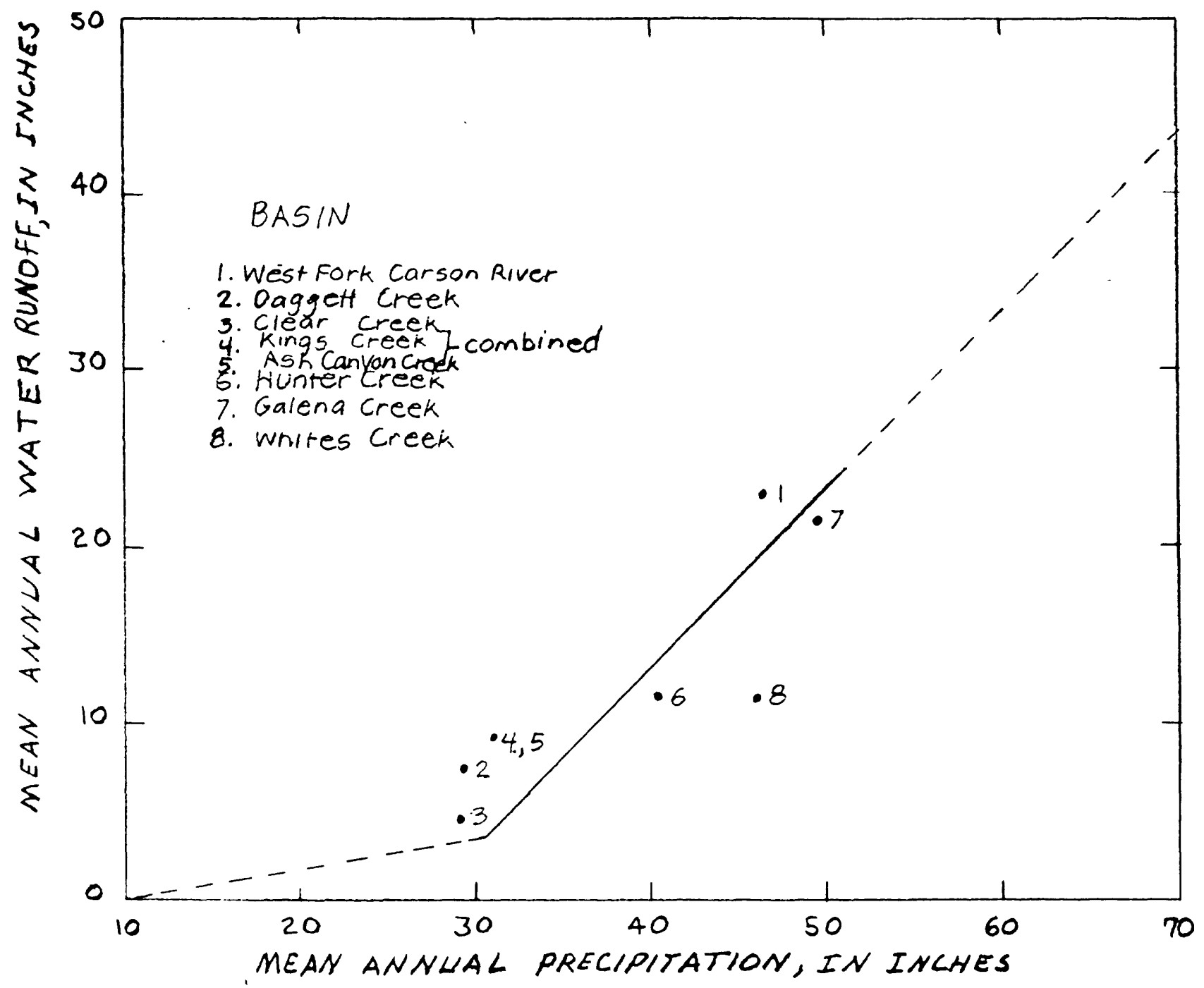

FIGURE 16.--Relation between mean annual precipitation and water runoff. 
TABLE 3.--Data on stream-gaging sites used in developing the relation between precipitation and runoff

\begin{tabular}{|c|c|c|c|}
\hline $\begin{array}{l}\text { Gaging-station name } \\
\text { (and number) }\end{array}$ & $\begin{array}{c}\text { Drainage } \\
\text { area } \\
\text { (square miles) }\end{array}$ & $\begin{array}{l}\text { Mean annual } \\
\text { runoff } \\
\text { (inches) }\end{array}$ & $\begin{array}{l}\text { Estimated } \\
\text { annual } \\
\text { precipitation } \\
\text { (inches) }\end{array}$ \\
\hline $\begin{array}{l}\text { West Fork Carson River } \\
\text { at Woodfords, Calif. } \\
(10310000)\end{array}$ & 65.6 & 23.0 & 47 \\
\hline $\begin{array}{l}\text { Daggett Creek near } \\
\text { Genoa, Nev. } \\
(10310400)\end{array}$ & 3.8 & 7.4 & 29 \\
\hline $\begin{array}{l}\text { Clear Creek near Carson } \\
\text { City, Nev. } \\
\text { (10310500) }\end{array}$ & 15.0 & 4.9 & 29 \\
\hline $\begin{array}{l}\text { Kings Canyon Creek near } \\
\text { Carson City, Nev. } \\
\text { (10311100) }\end{array}$ & $4.1)$ & & \\
\hline $\begin{array}{l}\text { Ash Canyon Creek near } \\
\text { Carson City, Nev. } \\
\text { (10311200) }\end{array}$ & $5.2\}$ & 9.3 & 31 \\
\hline $\begin{array}{l}\text { Hunter Creek near } \\
\text { Reno, Nev. } \\
\text { (10347600) }\end{array}$ & 11.5 & 11.7 & 40.5 \\
\hline $\begin{array}{l}\text { Galena Creek near } \\
\text { Steamboat, Nev. } \\
(10348900)\end{array}$ & 7.1 & 21.5 & 49.5 \\
\hline $\begin{array}{l}\text { Whites Creek near } \\
\text { Steamboat, Nev. } \\
(10349700)\end{array}$ & 9.0 & 11.4 & 46 \\
\hline
\end{tabular}


Briefly stated, the procedure used to develop the precipitation-runof relation as described by Rantz (1974) and Arteaga and Durbin (1978), was as follows. First, precipitation values were developed for each of the gaged drainage basins listed in table 3. The precipitation-runoff relation was then established by a trial-and-error procedure in which a first-trial relation was obtained by plotting mean annual basin-wide runoff against mean annual basinwide precipitation. Runoff values for the trial relation were then applied to area-weighted precipitation values for each basin to compute mean annual runoff. For each basin, the computed runoff was compared to the measured runoff, and adjustments were made to the precipitation-runoff relation until it produced acceptable agreement between the computed and measured runof $f$ for each basin. Figure 17 shows the comparison between measured and computed runoff.

The final relation between mean annual precipitation and runof $f$ (figure 16) consists of two straight-line segments. The lower segment (mean annual precipitation from 10 to about 30 inches) represents the condition where a unit increase in precipitation results in less than a unit increase in runoff. The physical significance is that, in the lower precipitation range, increased precipitation, in excess of soil moisture deficits, causes an increase in vegetation density and a resulting increase in water consumed by that vegetation. The upper segment of the relation (mean annual precipitation greater than about 30 inches) represents the condition where a unit increase in precipitation results in a unit increase in runoff. Physically, the vegetation density has reached a maximum for the drainage basin, and consumptive use therefore does not increase with increasing precipitation.

To obtain a representative, area weighted, runoff for the basin, the precipitation-runof $f$ relation was applied to each subbasin in the Galena Creek drainage except for Galena Creek where measured runoff data were used. A map (figure 18) was developed from the precipitation-runoff relation (figure 16) to transform contours of equal mean annual precipitation (figure 15) into lines of equal mean runoff. This technique estimates the amount of water available for use annually, at the mountain front, including streamflow and all ground-water recharge, and for the Galena Creek ground-water basin is about 10,000 acre-ft/yr.

Relation between precipitation and evapotranspiration.--Figure 19 shows the relation between mean annual precipitation and evapotranspiration for the Galena Creek drainage basin. The relation was constructed directly from the precipitation-runof $f$ relation ( $f$ igure 16 ) by subtracting runoff from mean annual precipitation.

Evapotranspiration map.--The precipitation-evapotranspiration relation shown in figure 19 was used to construct a map of the study area showing lines of equal mean annual evapotranspiration. The map was constructed by dividing the basin into cells of equal area and determining the average precipitation value for each cell. Then, by using the precipitation-evapotranspiration relation shown in figure 19, a corresponding average evapotranspiration value for each cell was derived. The resultant map is shown in figure 20 .

The volume of mean annual, primary evapotranspiration for the Galena Creek drainage basin was estimated to be 22,000 acre-feet. 


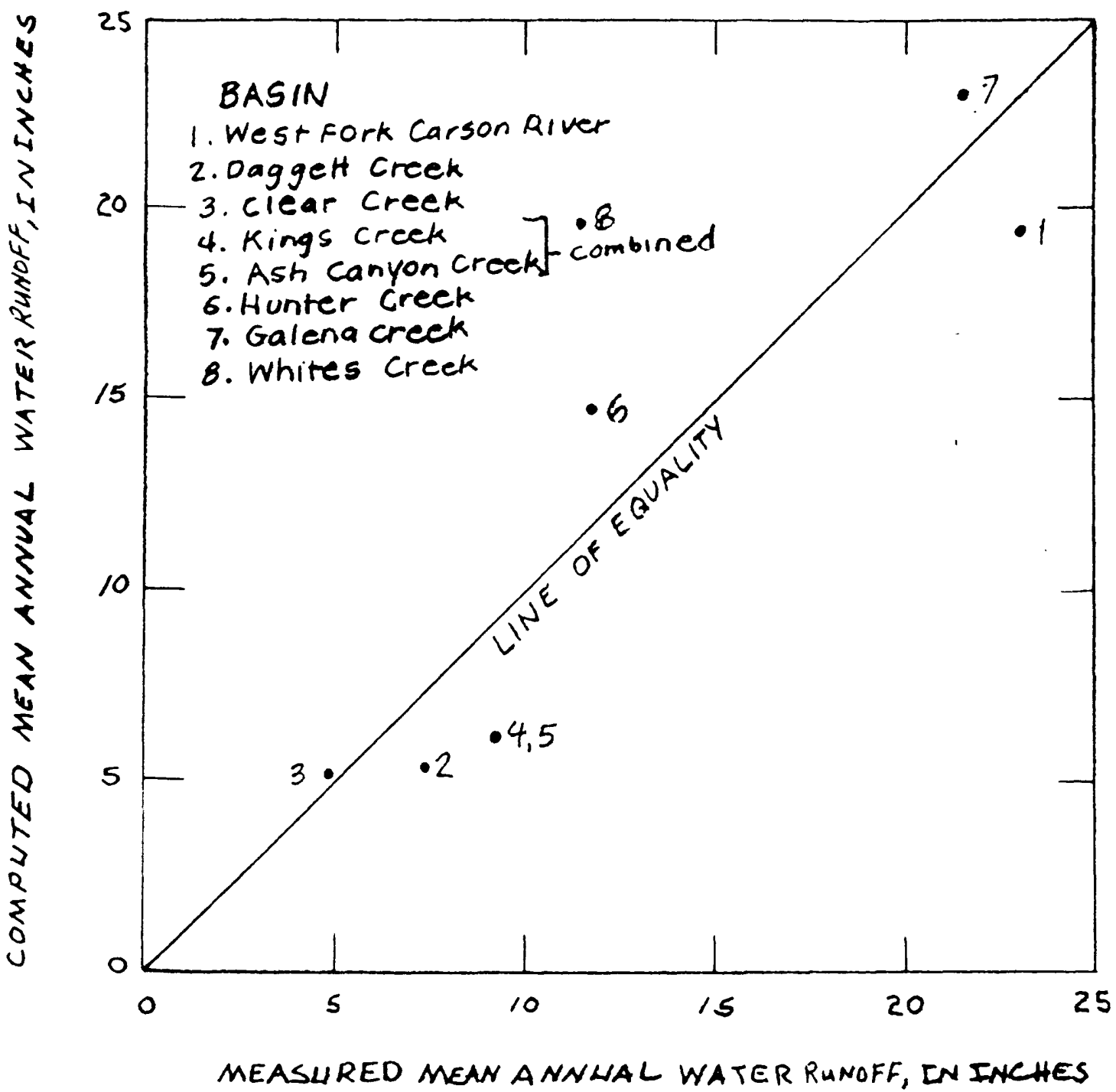

FIGURE 17.--Comparison between measured and computed water runoff. Computed values are based on precipitation-runoff relation. 


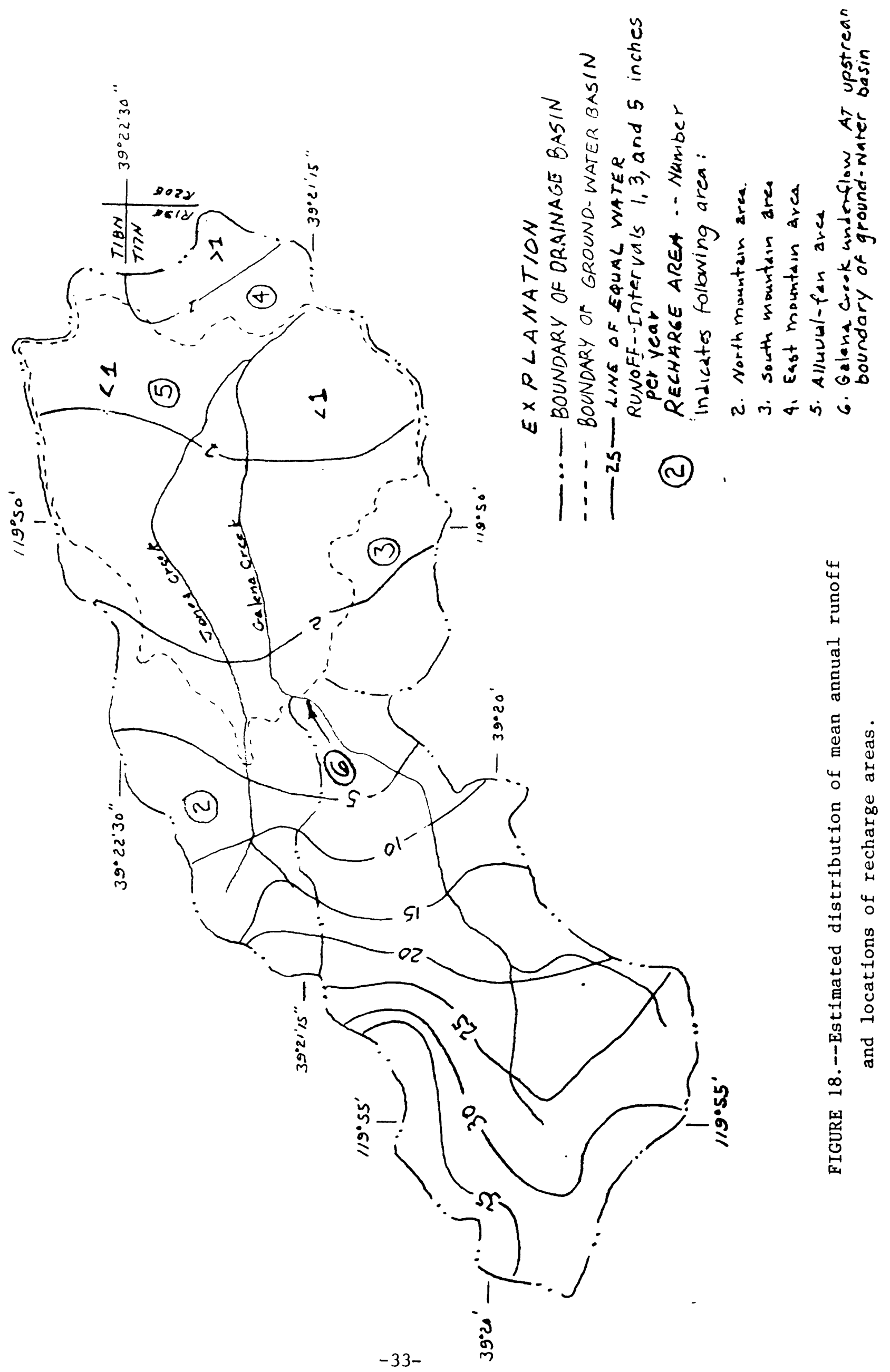




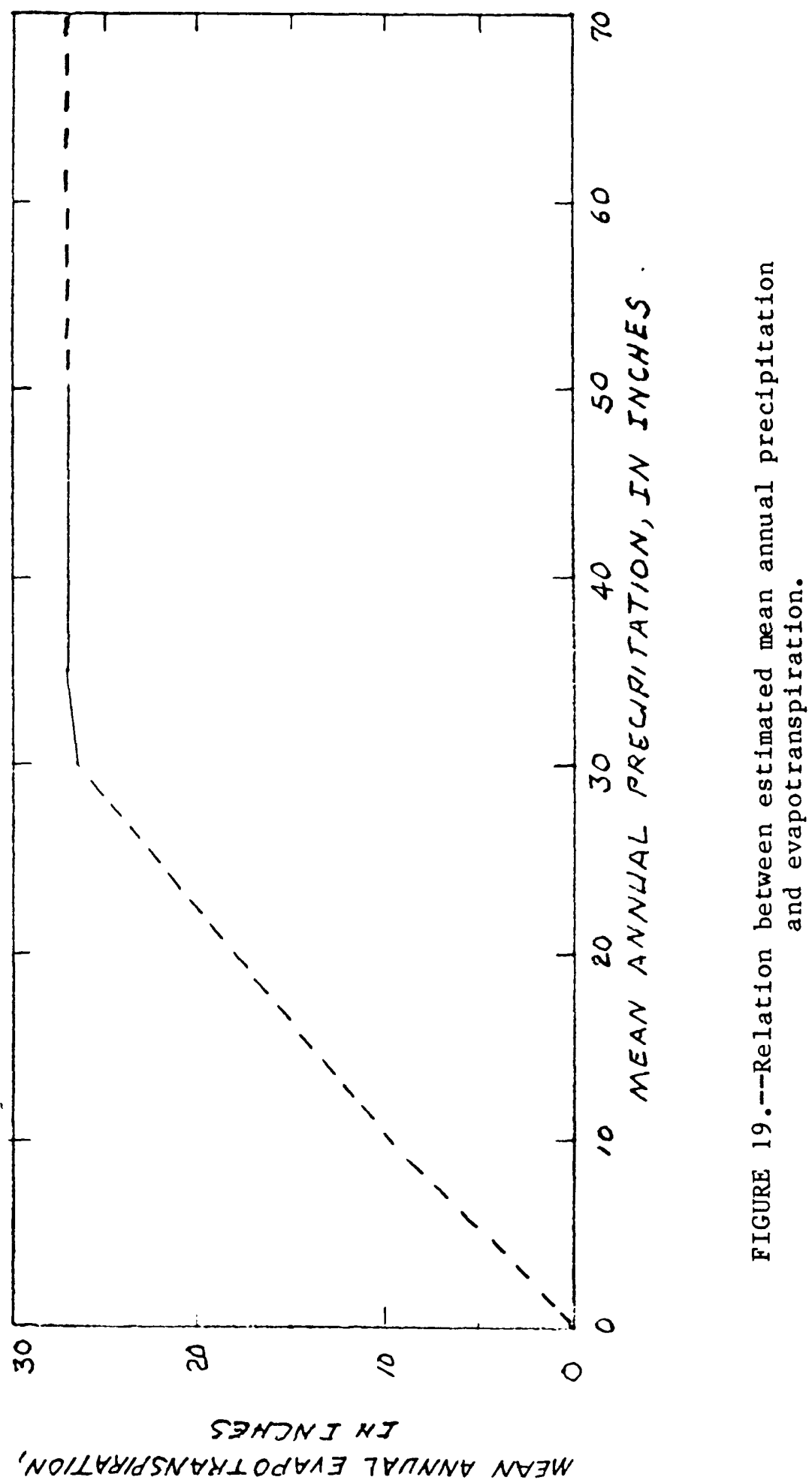




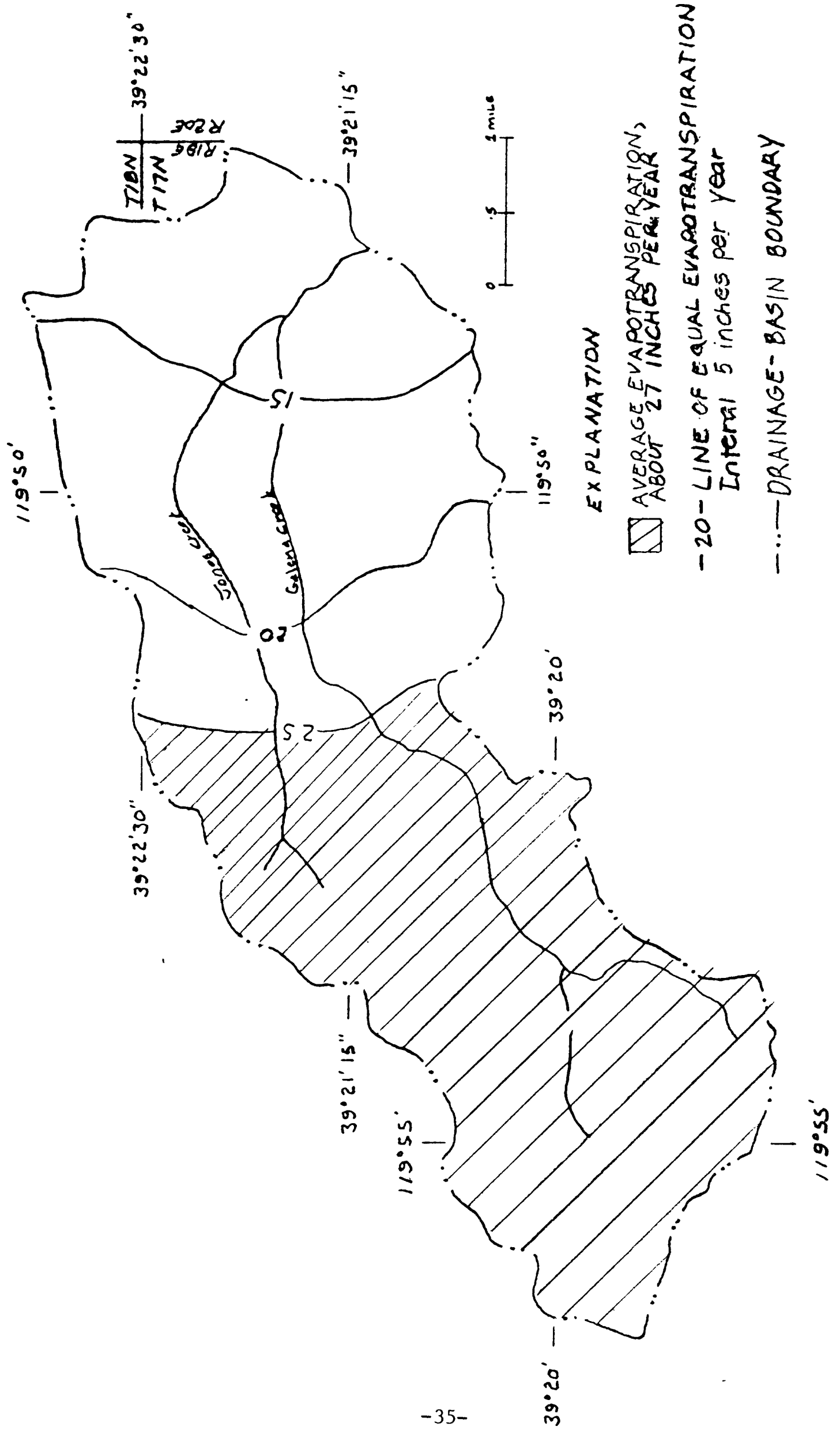

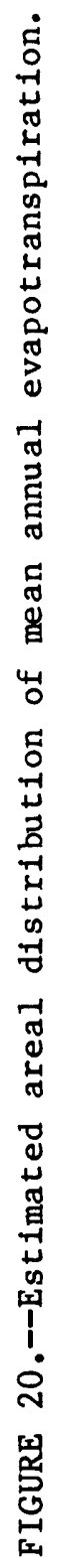




\section{Secondary Evapotranspiration}

About 300 acres of pastureland are irrigated from surface-water diversions in the Galena Creek drainage basin. Approximately 250 acres in the lower reach of Galena Creek are served by canals (not shown) that divert water down stream from the Galena Creek gaging station. The remaining 50 acres of pastureland are in the Jones Creek drainage (which is tributary to Galena Creek; see figure 1) and are served by an irrigation canal (not shown) that diverts water out of Galena Creek about 1.5 miles upstream from the Galena Creek gaging station. The evapotranspiration of the applied irrigation water, which is called secondary evapotranspiration, was estimated to be about 900 acre-ft/yr, on the basis of a net consumption of about $3 \mathrm{ft} / \mathrm{yr}$ (Robert Pennington, Nevada Division of Water Resources, oral communication, 1980). Parenthetically, net consumption equals total water consumption minus that supplied by direct precipitation.

Also contributing to secondary evapotranspiration is the estimated annual consumption of water by residential use in the study area (about 40 acre-feet in 1979). Thus, the total secondary evapotranspiration, which is the sum of irrigation use and residential use, is 940 acre-ft/yr.

\section{Surface-Water Outflow}

Surface water discharges from the Galena Creek drainage basin at two locations. First, Galena Creek leaves the basin at a point on the eastern boundary (figure 1); the estimated mean annual flow of Galena Creek at this point is about 3,700 acre-feet, on the basis of miscellaneous streamflow measurements. Second, a ditch diverts water from Galena Creek near the bedrock-alluvial contact on the western edge of the ground-water basin and transports it out of the basin and into the Browns Creek basin at a point on the southern boundary of the Galena Creek basin (figure 11). The ditch discharges about 1,000 acre-feet of water annually from the Galena Creek basin, on the basis of miscellaneous streamflow measurements. Therefore, the estimated total mean annual surface-water outflow from the basin is 4,700 acre-feet.

The estimate of streamflow in Galena Creek needs further clarification. The estimate is intended to represent the streamflow of Galena Creek as if accretions to streamflow from ground water were not present. Yet Galena Creek does gain ground water in about the last half-mile of its lower reach prior to exiting the basin. Data were not available to separate ground-water accretions from surface-water return flows resulting from irrigation.

An estimate of Galena Creek outflow from the study area was developed as shown schematically in figure 21. The mean annual discharge at the Galena Creek gaging station near Steamboat (figure 11) is about 5,900 acre-ft/yr. This long-term estimate has been obtained by correlating gaged Galena Creek flows with the long-term records for the West Fork of the Carson River near Woodfords, Calif., about 40 miles south of the study area. On the basis of miscellaneous discharge measurements downstream from the Galena Creek gage, conveyance losses from the stream channel (about $400 \mathrm{acre}-\mathrm{ft} / \mathrm{yr}$ ) and from diversion ditches (about 800 acre-ft/yr) total approximately 1,200 acre-ft/yr. 


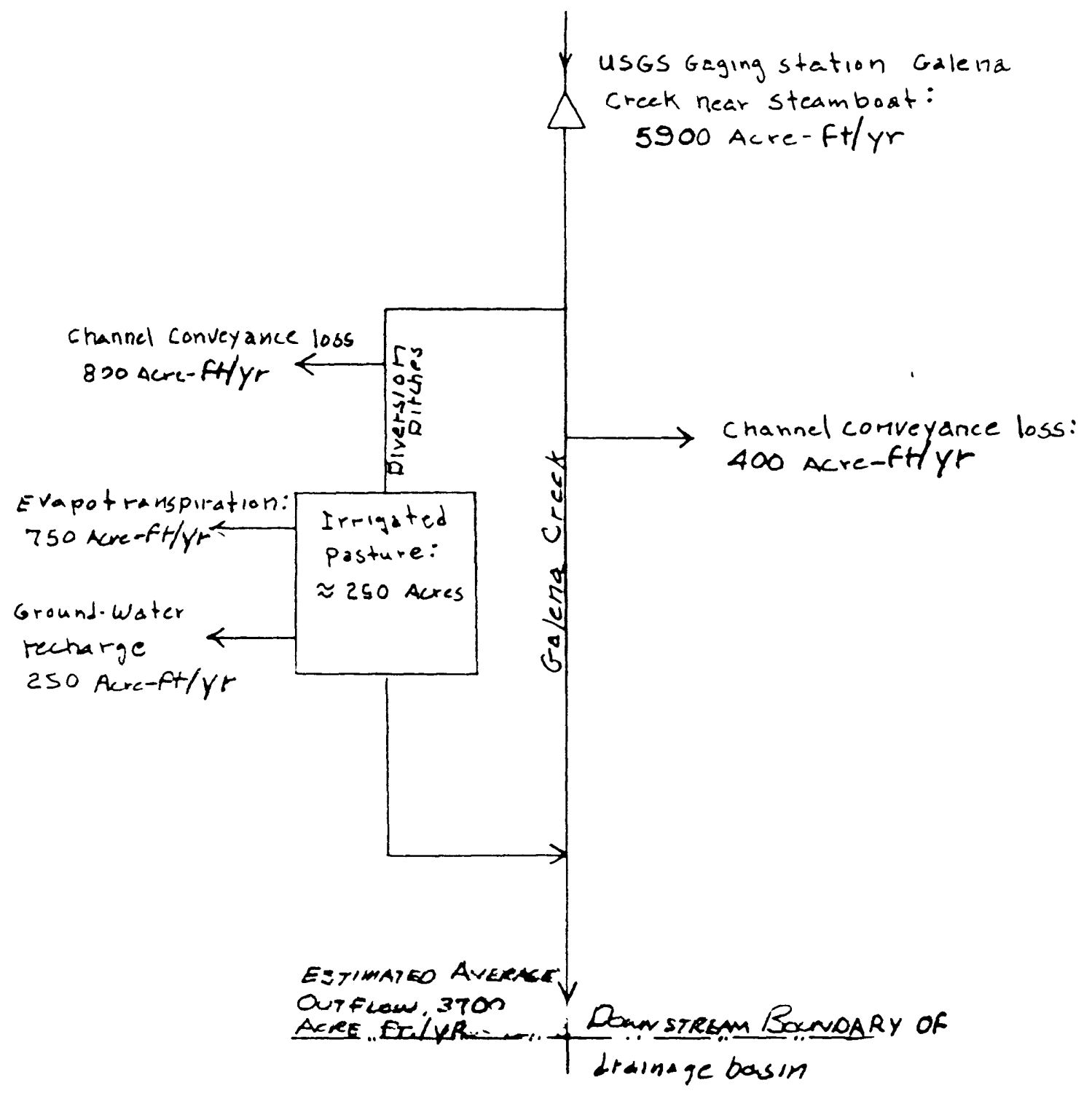

FIGURE 21.--Schematic flow diagram for lower reach of Galena Creek, showing estimated surface-water gains and losses. 
Loss of surface water by evapotranspiration and ground-water recharge resulting from irrigation of about 250 acres of pasture in the lower reach is estimated to be 1,000 acre-ft/yr. The remaining irrigated acreage, about 50 acres, is not included in this computation because it is located in the Jones Creek drainage. Jones Creek is ephermeral in its lower reach and the surface-water flow to Galena Creek was not estimated. Thus, the surface-water flow of Galena Creek at the lower boundary of the study area is an estimated 3,700 acre-ft/yr [that is, $5,900-(400+800+1,000)]$. This value compares surprisingly well with the results of a more direct estimation technique.

Flow measurements were made at the site where Galena Creek exits the study area (figure 11) and compared to measurements and gaged flow as recorded by Claude Dukes (Federal Watermaster, written communication, 1979), at the eastern edge of the Steamboat Hills where Galena Creek enters Pleasant Valley, an additional 0.8 mile downstream (not shown on figure 11 ). Over this distance, Galena Creek is estimated to gain about 600 acre-ft/yr between the study-area boundary and the Federal Watermaster's gaging station at the eastern edge of the Steamboat Hills. Adjusting this gaging-station record to a long-term average of 4,300 acre-ft/yr and subtracting the $600-a c r e-f t / y r$ gives an estimated value of 3,700 acre-ft/yr at the study-area boundary.

\section{Ground-Water Outflow}

Up to this point, all items in the water-budget equation have been estimated directly and indirectly except ground-water outflow, which is here calculated by difference. Refering to table 2, precipitation is 32,000 acre$\mathrm{ft} / \mathrm{yr}$, evapotranspiration (primary and secondary) is 22,900 acre- $\mathrm{ft} / \mathrm{yr}$, and surface-water outflow (Galena Creek and Browns Creek diversion) is 4,700 acre$\mathrm{ft} / \mathrm{yr}$. Solving the water-budget equation, previously discussed, for groundwater outflow $(G)$ yields a value of 4,400 acre-ft/yr.

\section{WATER BUDGET FOR THE GROUND-WATER BASIN}

\section{The Water-Budget Equation}

The ground-water budget for the Galena Creek ground-water basin is an accounting of all the ground water entering and leaving the basin. The water entering the system is recharge, which has two components, primary and secondary. Primary recharge is the natural recharge to the basin, whereas secondary recharge is the recharge of water as a result of domestic or agricultural use. Water leaving the system includes natural outflow by (1) underflow, (2) seepage into Galena Creek, and (3) spring discharge, and outflow as pumpage.

Water entering and leaving the ground-water basin is shown schematically in figure 22. The relation between components can be described mathematically by the steady-state water-budget equation in which inflow equals outflow:

$$
R_{1}+R_{2}=G+Q,
$$

where $R_{1}=$ primary ground-water recharge;

$R_{2}=$ secondary recharge;

$G=$ ground-water outflow; and

$Q=$ pumpage. 


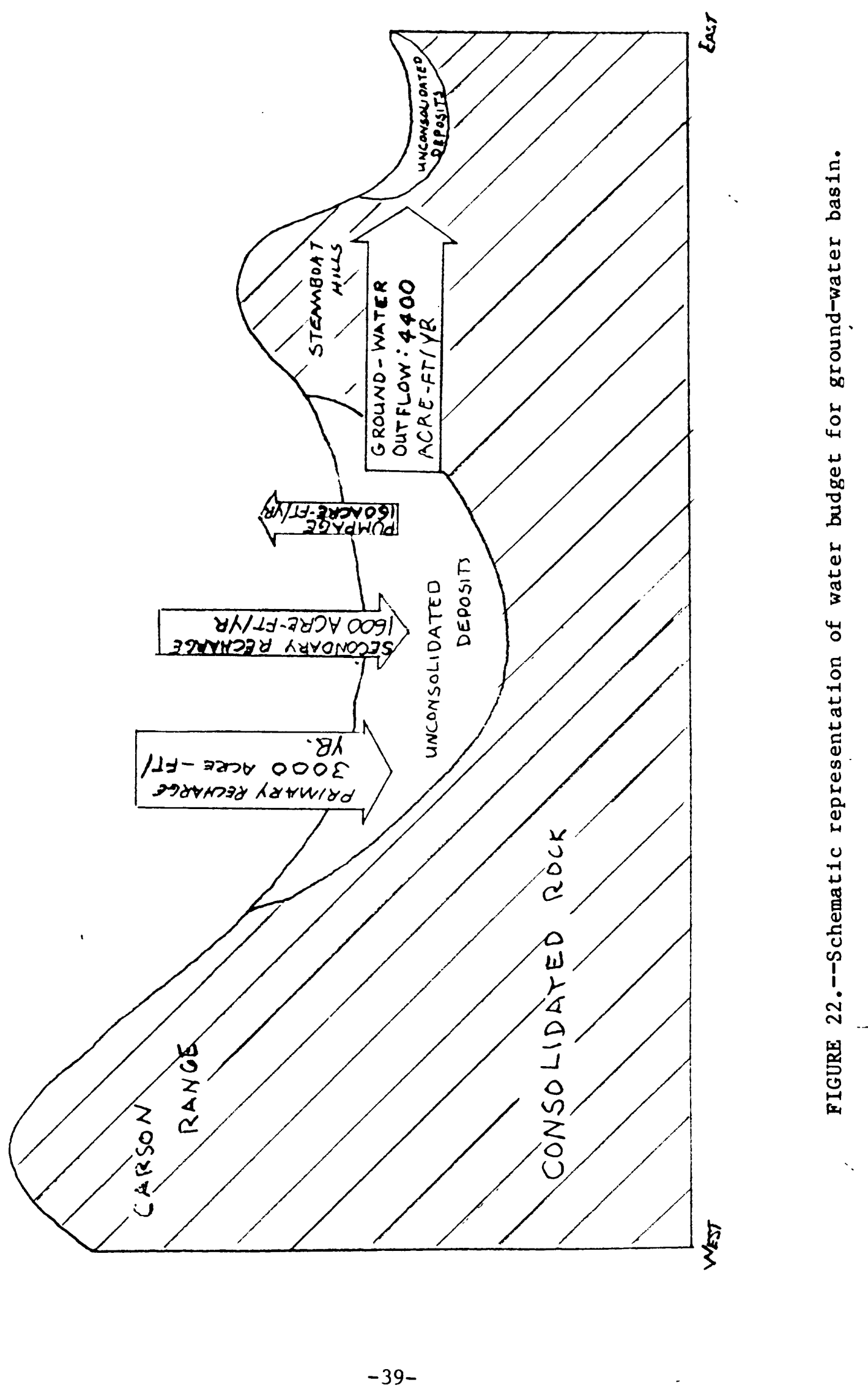


The following sections of the report describe the items of the waterbudget equation in more detail, and table 4 lists the value for each of the items.

\section{Ground-Water Outflow}

Outflow from the Galena Creek ground-water basin is 4,400 acre-ft/yr, as determined by difference between the estimated elements of the water-budget for the drainage basin (table 2). This outflow occurs in two areas of the groundwater basin (figure 9): (1) as underflow along the northern and northeast boundary, and (2) at the eastern edge of the basin as springs and seepage along the lower reaches of Galena Creek with underflow infiltrating into the volcanic rocks of the Steamboat Hills. The individual quantities are estimated to be 2,700 and 1,700 acre-ft/yr, respectively, on the basis of calculations made by using a mathematical model of the ground-water basin (see later section of this report).

\section{Pumpage}

At present (1979) about 250 single-family dwelling units are in the Galena Creek basin. These units obtain water from individual wells or from small cooperative water systems that use wells. Domestic water use has been characterized as follows, on the basis of field observations and data for water meters within the study area and for nearby water-delivery systems:

1. An average household comprises three people.

2. Water demand averages about 190 gallons per day per person (including an allowance for lawn and garden watering and sprinkler irrigation of small pastures).

3. Thus, an average single-family dwelling unit uses about 210,000 gallons, or 0.64 acre-feet, per year.

On the basis of this rate, the 250 dwelling units in the Galena Creek basin account for a combined pumpage of about 160 acre-ft/yr.

\section{Ground-Water Recharge}

The Galena Creek ground-water basin is recharged principally by the direct infiltration and deep percolation of precipitation and by the deep percolation of water from stream channels. This is termed primary recharge. As previously mentioned, secondary recharge results from percolation of applied irrigation water and domestic waste water.

Primary recharge is by far the largest source of ground water. For reasons that will be apparent later, however, secondary recharge is discussed in detail first. 
TABLE 4.--Mean annual water budget for the ground-water basin 1

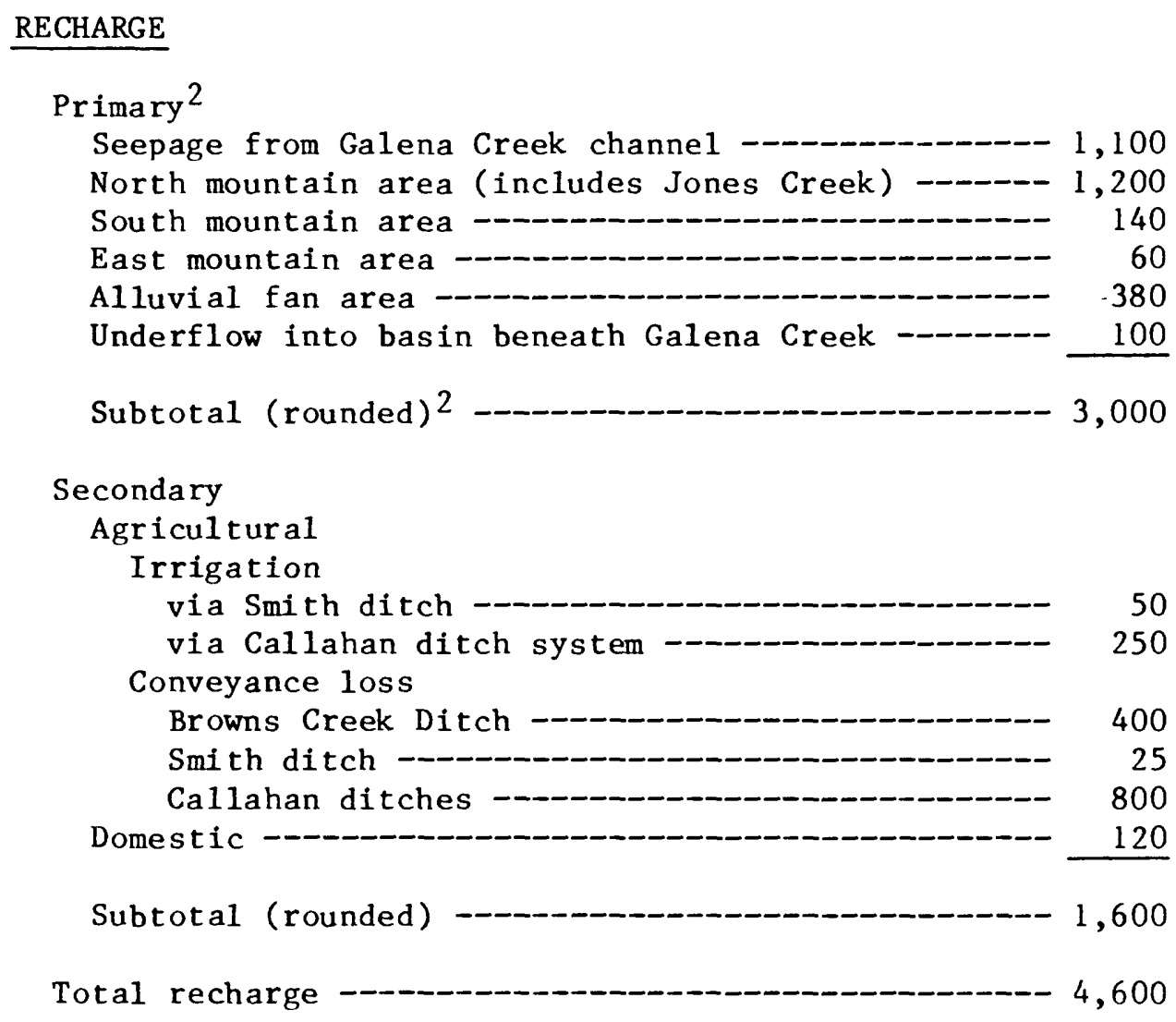

1 See report section titled "Significance of Numerical Values."

2 Total primary recharge determined by difference (that is, total discharge minus secondary recharge). Individual components of primary recharge are discussed in text. 


\section{Secondary Recharge}

Secondary recharge has three components; (1) recharge from applied irrigation water, (2) recharge from conveyance loss from the diversion channels (not including Galena Creek), and (3) return of domestic pumpage to the ground-water system. Table 4 quantifies these various types of secondary recharge.

Applied irrigation water.--About 300 acres of meadowland in the Galena Creek basin is irrigated. Most of the irrigated land (250 acres, on Callahan property not shown) is along the lower reaches of Galena Creek. Additional irrigated land of about 50 acres is near the western edge of the ground-water basin adjacent to Jones Creek.

Recharge of applied irrigation water has not been measured. A crude estimate can be made, however, by assuming that irrigation water is applied at the annual rate of 4 acre-ft/acre and that the net consumption is about 3 acre-ft/acre. Using these reasonable assumptions, the annual secondary ground-water recharge from applied irrigation water is about 1 acre-ft/acre, or about 300 acre-feet.

Conveyance Zoss.--These losses were determined by making a series of discharge measurements at the point of diversion and near the downstream end of the diversion. The difference between these measurements was assumed to be the conveyance loss (table 4). Galena Creek is not included here because it is a primary source of recharge to the basin. Values for Jones Creek are not 1 isted either because it is ephemeral throughout most of its lower reach.

Domestic use.--Ground water pumped for domestic supply is used mostly within the dwellings and is disposed of in individual septic tank drain fields. Relatively little water is used for domestic irrigation, as most of the homes have, at most, only small lawns and little other vegetation requiring irrigation. Consequently, most of the water pumped for domestic supply probably returns to the ground-water basin after use.

As in the case of applied irrigation water, data are not available to determine secondary ground-water recharge from the domestic use of water. On the basis of assumptions similar to those of Harril1 (1973, page 63), about 75 percent of the domestic pumpage, or about 120 acre-ft/yr, is thought to return to the ground-water basin.

The estimated total secondary recharge, then, is the sum of the irrigation and conveyance losses plus return of domestic water, or about 1,600 acre-ft/yr (table 4).

\section{Primary Recharge}

Given information developed above on ground-water outflow, pumpage, and secondary recharge, primary ground-water recharge can be calculated by difference in the water-budget equation for the ground-water basin. Solving the water-budget equation for primary recharge $\left(R_{1}\right)$ gives a value of about 3,000 acre-ft/yr (that is, 4,600 acre-ft/yr of total discharge minus 1,600 acre-ft/yr of secondary recharge; see table 4). 


\section{Distribution of Primary Ground-Water Recharge}

Primary ground-water recharge for the Galena Creek ground-water basin is estimated to be 3,000 acre-ft/yr. This recharge takes place in several areas of the basin, as indicated in figure 23. The recharge comprises: Seepage loss from the Galena Creek channel within the ground-water basin, surface- and ground-water inflow to the basin from the north-mountain (including Jones Creek), south-mountain, east-mountain, and alluvial-fan areas, and ground-water underflow into the basin beneath Galena Creek. Table 4 lists the respective estimates of recharge from these areas to the ground-water basin.

\section{Seepage from Galena Creek Channel}

Seepage from the channel of Galena Creek is a major source of recharge to the ground-water basin. In the channel reach that overlies the groundwater basin (figure 23), seepage loss provides about 1,100 acre-ft/yr of ground-water recharge. This estimate was derived from many discharge measurements of Galena Creek at a point near where it exits the mountain block near State Highway 27 (figure 11). These flows were compared with the downstream gaged record (figure 11) and the difference was assumed to be seepage loss. This loss rate was extrapolated to include the remainder of the channel downstream from the gaging station where seepage occurs. Diversions were accounted for in this computation.

\section{Diffuse Sources of Primary Recharge}

Seepage from Galena Creek is a "line source" of ground-water recharge, whereas the other sources contribute more areally diffuse recharge. In these latter areas, recharge can result from the infiltration of ephemeral stream-flow, the subsurface movement of water down mountain slopes and into the alluvial deposits of the ground-water basin, and direct penetration of precipitation into the ground-water basin. For each of these sources, the entire inflow of the contributing area probably becomes ground-water recharge. Jones Creek is an exception to this during periods of above average runoff, however, there are no data to define this runoff.

The map (figure 18) showing lines of equal mean-annual water runoff and the location of the recharge areas was used as the basis for estimating diffuse primary recharge.

Estimates of ground-water recharge from the north, south, and east mountain areas and the alluvial-fan area are listed in table 5. In the north and south mountain area the recharge may be about evenly distributed along the boundary of the ground-water basin. The distribution of inflow from the east mountain area, the Steamboat Hills, is uncertain due to the presence of minor springs and seeps in close proximity to Galena Creek. There is a reasonable chance that this minor amount of ground-water inflow discharges directly into Galena Creek. This inflow was not used as a recharge value in the ground-water model discussed later. 


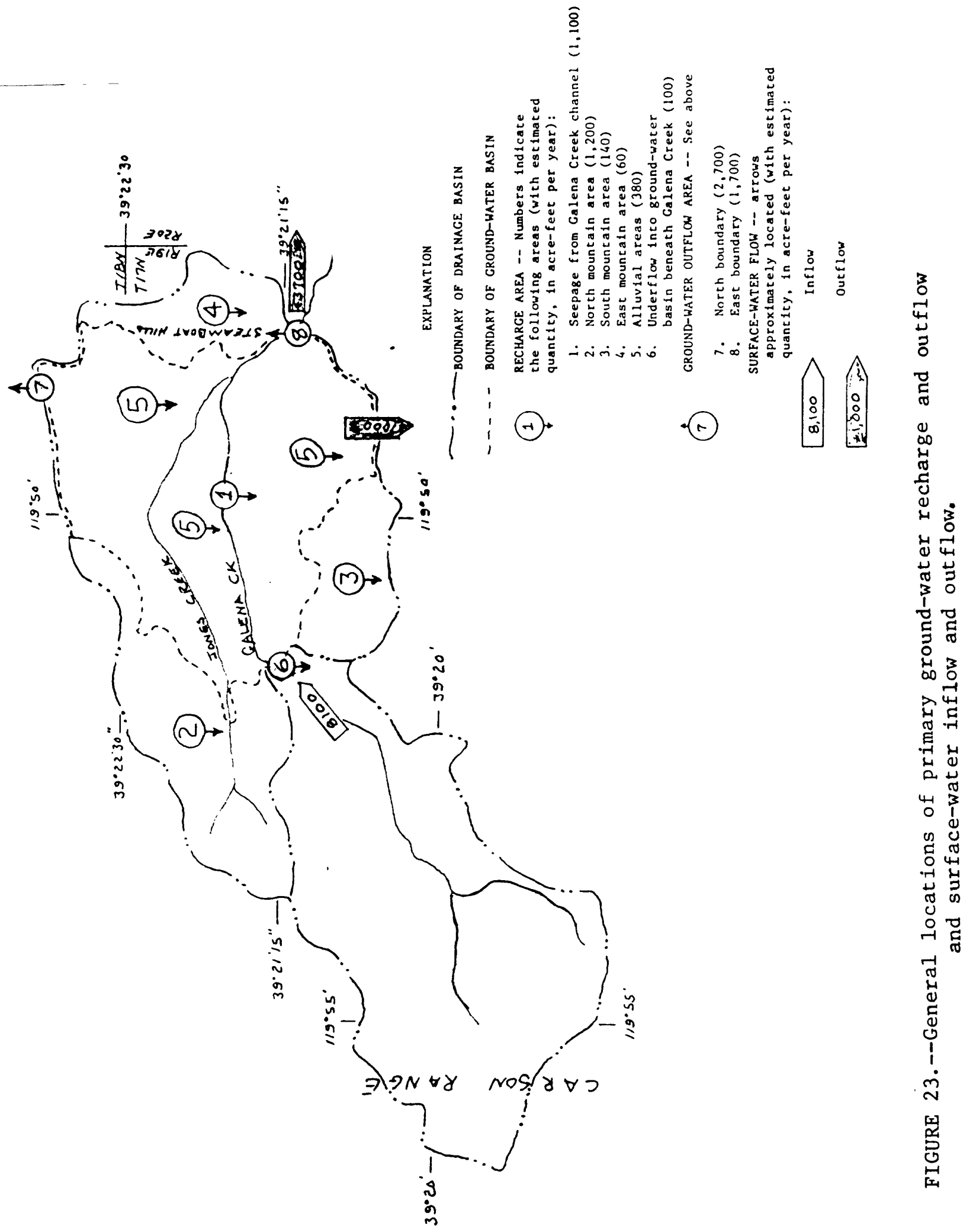


TABLE 5.--Estimates of primary ground-water recharge from diffuse sources

\begin{tabular}{|c|c|c|c|}
\hline \multirow[b]{2}{*}{$\begin{array}{l}\text { Recharge area } \\
\text { (figure } 23 \text { ) }\end{array}$} & \multirow{2}{*}{$\begin{array}{l}\text { Drainage } \\
\text { (square } \\
\text { miles) }\end{array}$} & \multicolumn{2}{|c|}{$\begin{array}{l}\text { Estimated mean annual } \\
\text { ground-water recharge }\end{array}$} \\
\hline & & Inches & $\begin{array}{l}\text { Acre-feet } \\
\text { (rounded) }\end{array}$ \\
\hline $\begin{array}{l}\text { North mountain area } \\
\text { South Mountain area } \\
\text { East mountain area } \\
\text { Alluvial-fan area }\end{array}$ & $\begin{array}{r}2.55 \\
1.46 \\
1.05 \\
a 5.54\end{array}$ & $\begin{array}{l}8.9 \\
1.8 \\
1.1 \\
1.3\end{array}$ & $\begin{array}{r}1,200 \\
140 \\
60 \\
380\end{array}$ \\
\hline Total (rounded) & 10.6 & -- & 1,800 \\
\hline
\end{tabular}




\section{Underflow into Ground-Water Basin \\ Beneath Galena Creek}

The total estimated primary recharge to the Galena Creek ground-water basin is 3,000 acre-ft/yr. The sum of seepage from Galena Creek and diffuse recharge sources is about 2,900 acre-ft/yr, which leaves a residual of about 100 acre-ft/yr of primary ground-water recharge that has not been identified as to source. That residual can, however, be accounted for as stream-channel underflow from the upper part of the Galena Creek drainage basin (figure 23). That underflow enters the ground-water basin at the point where Galena Creek enters the basin. This residual underflow of 100 acre-ft/yr seems reasonable when compared with values estimated by Glancy and Katzer (1975, table 18, page 51) for other Sierra Nevada streams.

\section{WATER-BUDGE T SUMMARY}

Another way of defining the available water resource is to compare basin inflow and outflow. Presumably, they equal each other and both represent the available water resource. Table 6 lists these values and shows that the average annual surface-water and ground-water inflow to the ground-water basin totals an estimated 10,000 acre-feet. Because inflow equals outflow, this same amount of water exits the basin. Table 6 lists these outflows, including a minor amount of evapotranspiration from irrigation and urban use. Any additional consumptive use of the 10,000 acre-feet of water will be reflected in either reduced inflows to or reduced outflows from the basin, or both, depending on where the use occurs.

\section{Mode1 Development}

In order to better understand the ground-water system, a mathematical model of the Galena Creek ground-water basin was developed to: (1) test the hydrologic conceptualization on the basin, (2) estimate the direction and magnitude of ground-water outflow from the basin, and (3) assist in identifying deficiences in the hydrologic data base. The model consists of a group of mathematical equations that are arranged in such a way that ground-water levels and ground-water outflow from the basin can be estimated. The use of the model is limited by the availibility of data. Thus, this reconnaissance tool is not intended for management use.

\section{Steady-State Simulation}

The model was developed in a form that can be used to simulate steady-state conditions within the ground-water basin. If a ground-water basin is in equilibrium with respect to the current climatic and development conditions (that is, no net change of water in storage), and inflow equals outflow, then the basin is considered to be in steady state. The Galena Creek ground-water basin is experiencing increasing ground-water withdrawals, but the amount of water is minor and for the purpose of this study the basin is considered in equilibrium. 
TABLE 6.--Summary of mean annual water budget for the Galena Creek ground-water basin1

\section{INFLOW}

Surface-water flow at mountain front (Galena Creek)

Ground-water flow at mountain front 2

8,100

1,900

Total inflow

10,000

\section{OUTFLOW}

Surface-water flow leaving basin 3

Ground-water flow leaving basin

Evapotranspiration from irrigation and domestic use

$$
4,700
$$

4,400

940

Total outflow (rounded)

10,000

1 See report section titled "Significance of Numerical Values."

2 Includes a minor amount of surface-water flow in Jones Creek, and the distributed aerial recharge over the alluvial fan area.

3 By way of Galena Creek $(3,700$ acre-ft/yr) and the export to Browns Creek (about 1,000 acre-ft/yr). 


\section{Governing Equation}

The principal technique used to evaluate the ground-water system in the Galena Creek basin was a computer model. The computer program used to model ground-water flow was written by Trescott (1975) and modified by Trescott and Larsen (1976). The program solves the basic ground-water equation in three dimensions, but for this study, the equation was simplified to solve for only two dimensions by assuming only horizontal flow. In addition, the storage term in Trescott's program was assumed to be zero because the simulations were steady-state. Thus, the ground-water flow equation of Trescott (1975, equation 4) can be simplified to the following equation:

$$
\frac{\partial}{\partial x}\left[K_{x} \cdot z \frac{\partial h}{\partial x}\right]+\frac{\partial}{\partial y}\left[K_{y} \cdot z \frac{\partial h}{\partial y}\right]+R^{\prime}-Q^{\prime}=0,
$$

where $\mathrm{K}_{\mathrm{x}}$ = hydraulic conductivity in the $\mathrm{x}$ direction, in feet per second;

$\mathrm{K}_{\mathrm{y}}=$ hydraulic conductivity in the $\mathrm{y}$ direction, in feet per second;

$\frac{\partial h}{\partial x}$ change in hydraulic head in the aquifer with respect to the

$\frac{\partial}{\partial x} \quad x$ direction;

$\frac{\partial h}{\partial y}=$ change in hydraulic head in the aquifer with respect to the

$\frac{\partial y}{\partial y}$ y direction;

$\frac{\partial}{\partial x}=$ change in the bracketed term with respect to the $x$ direction;

$\frac{\partial}{\partial y}=$ change in the bracketed term with respect to the $\mathrm{y}$ direction;

$z=$ saturated thickness of the unconsolidated deposits;

$R^{\prime}=$ recharge to the aquifer per unit area; and

$Q^{\prime}=$ discharge from the aquifer per unit area.

In Trescott's program, the continuous derivatives are replaced with finite-difference approximations at a point or node. Surrounding each node is a cell with dimensions $x, y$, and $z$ in which the hydraulic properties are assumed uniform. The program solves the finite-difference approximations using a strongly implicit procedure. This is done by iterating through the finite-difference approximations until the head change between the previous iteration and the current iteration is less than a specified amount.

The Galena Creek area was divided into model cells with horizontal dimensions of 2,000 feet. Like al1 ground-water systems, the Galena Creek area is of finite and vertical extent. Hydrologic conditions at the boundaries of the simulated ground-water system must duplicate the actual boundary conditions, as nearly as possible, to obtain acceptable solutions in the remainder of the simulated system. The boundary conditions used in the Galena Creek model are described in the following section.

General Features of the Model

The model is constructed by specifying boundary conditions, recharge to the ground-water basin, and aquifer properties of the basin. The model grid, the boundaries, and the geographical features of the Galena Creek ground-water basin are shown in figure 24 . 


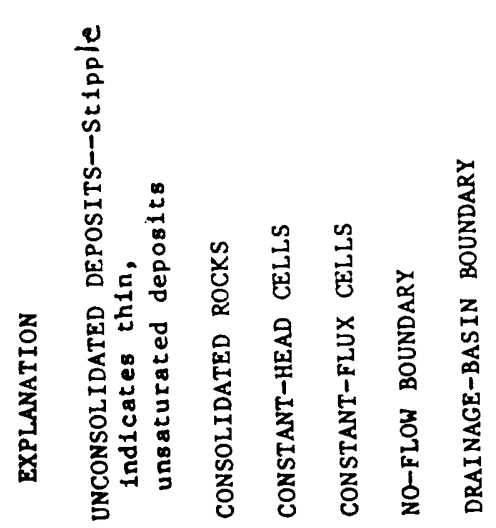

网㥸区|

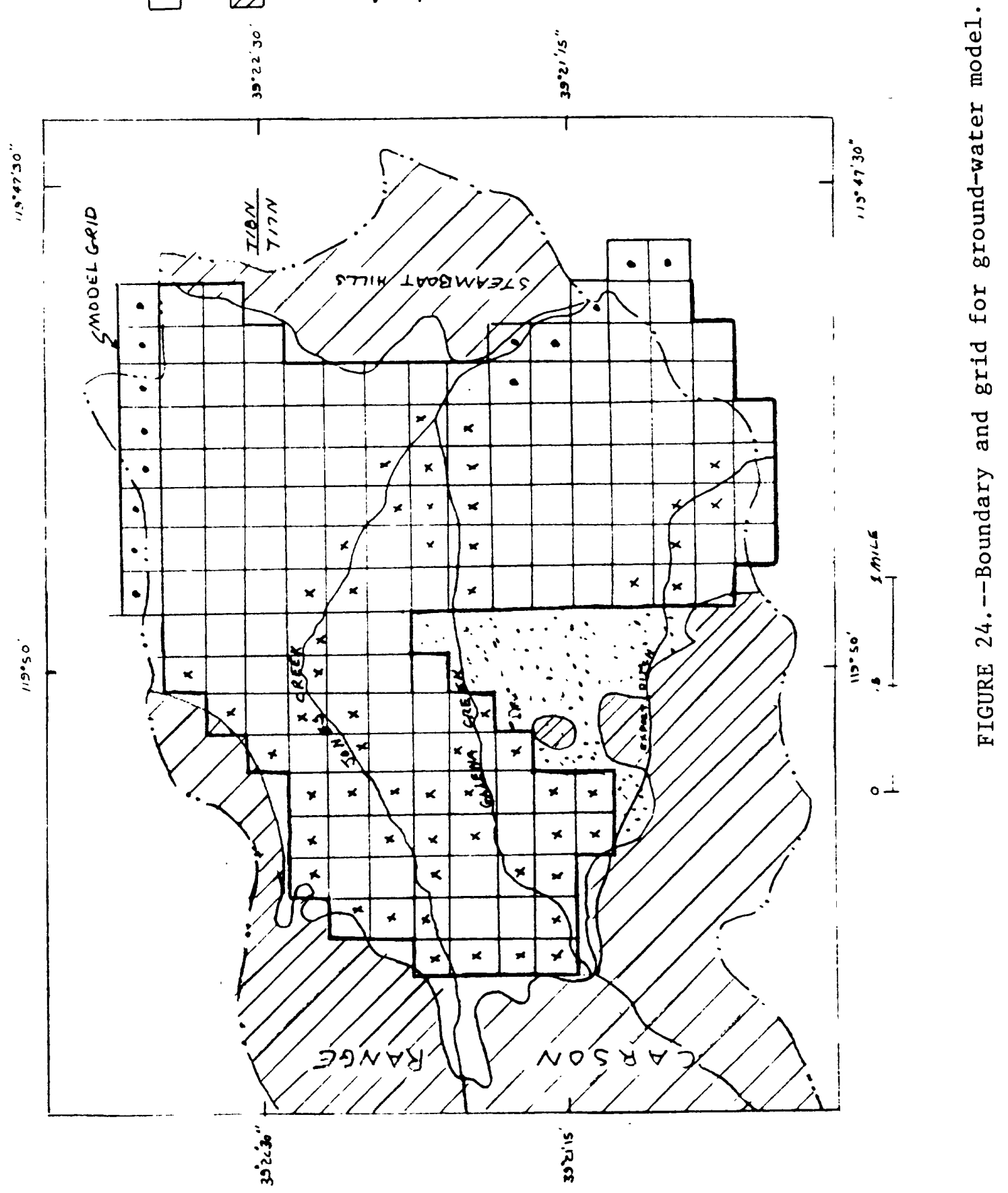


Model boundaries.--Boundaries of the model for the Galena Creek groundwater basin are described as no-flow, constant-head, and constant-flux. These boundaries are shown in figure 24 .

The no-flow boundaries represent poorly permeable consolidated rock that borders the basin, and the unsaturated segments of unconsolidated deposits in the south-central part of the basin. The model does not simulate ground-water movement across these boundaries. In that regard, part of the unconsolidated deposits (stippled, in figure 25) represent an area of thin and perhaps saturated unconsolidated deposits overlying bedrock. The model would not approximate the observed water levels in adjacent areas until this part of the basin was defined as a no-flow boundary. This conflicts with the generalized observed water levels shown in figure 10 and underscores the utility of using a reconnaissance model to test the hydrologic conceptualization of the basin. There are virtually no ground-water level data in this area; therefore, the water levels shown in figure 10 are generalized.

Constant-head boundaries are intended to represent segments of the ground-water basin bounded by permeable unconsolidated deposits. These are along the northern and eastern boundaries of the basin (figure 24), where ground water flows out of the basin, and they represent the altitude of the water table at these boundaries. The model simulates ground-water movement across these boundaries in proportion to the ground-water gradient at the boundary.

The constant-flux boundaries represent estimates of ground-water recharge to the basin: (1) Recharge from the precipitation-runof $\mathrm{f}$ relation (figure 16 and table 4) is distributed areally along the no-flow boundaries and uniformly over the alluvial fan area, (2) recharge from channel seepage losses of Galena Creek, Jones Creek, and the diversion ditches (table 4) is distributed equally along the channels, and (3) recharge from irrigation and urban use (table 4) is distributed in the area it occurs and is not shown in figure 24.

Recharge and discharge.--Recharge values developed from the water budget for the ground-water basin were used in conjunction with the other hydrologic values to define the direction and magnitude of the ground-water discharge. These recharge and discharge values are listed in table 4 and flow directions are shown in figure 9. The primary and secondary recharge values are represented in the model as constant-flux cells.

Transmissivity.--Transmissivity is a measure of the ability of the unconsolidated deposits of the ground-water basin to transmit water. It is the rate at which water would flow through the entire saturated thickness of unconsolidated deposits under a unit hydraulic-head gradient. A related term is hydraulic conductivity, which is the rate at which ground water would be similarly transmitted through a unit thickness of unconsolidated deposits. 
Transmissivity and hydraulic conductivity are related mathematically: transmissivity equals the product of the average hydraulic conductivity and the saturated thickness of unconsolidated deposits. The saturated thickness is the distance between the water table and the bottom of the aquifer.

These concepts were used to prepare transmissivity estimates for the ground-water model on the basis of estimates of the saturated thickness and the depth-averaged hydraulic conductivity. Estimates of saturated thickness of unconsolidated deposits were taken from figure 6 (which shows the thickness of unconsolidated deposits) and figure 9 (which shows the depth to ground water below the land surface) and are shown in figure 25 . Estimates of an average basin-wide hydraulic conductivity were obtained from the trial-and-error procedure described below.

Model analysis.--Little direct information was available that could be used to estimate the average hydraulic conductivity of the unconsolidated deposits within the Galena Creek ground-water basin. The model was used to compute water levels based on trial values of hydraulic conductivity. The computed water levels were compared to measured water levels (figure 10). If the comparison was not judged satisfactory, a new trial value of hydraulic conductivity was selected, and the process was repeated until an acceptable comparison was obtained. The calibration procedure assumed that the geographic variability of hydraulic conductivity in the basin could be adequately represented in the model with a single basin-wide value. The estimates ranged from 0.2 to 10 feet per day, with the estimated average hydraulic conductivity of 2 feet per day showing the best match between computed and observed water levels. Figure 26 shows the model-generated steady-state water levels for conditions as of 1979.

The computed steady-state ground-water levels (figure 26) do not match the observed water levels (figure 10) very well, except in direction of flow. There are some unusual differences which again emphasize the importance of using a reconnaissance tool, such as the model, to aid in understanding the hydrology of the basin. The first major difference is in the no-flow boundary area in the south-central part of the basin,which was previously discussed. The second major difference is in the width of the north-northeast boundary. The model-generated flow boundary is much greater than the observed flow boundary. We suspect there are 3 main reasons for this: (1) The no-flow boundary area (stippled, in figure 24) previously discussed is forcing more ground water to the north, (2) extensive north-south faulting in the northeast part of the basin (figure 3 ) is causing a discontinuity in water levels that is not adequately defined, and (3) sparse data requires generalizations.

The hydraulic properties of the ground-water system and the boundary conditions have been approximated by the modeling effort. Thus, the degree of uncertainty in the model results is large. Nevertheless, the match between measured and computed water levels is reasonable considering the limitations in the data. 

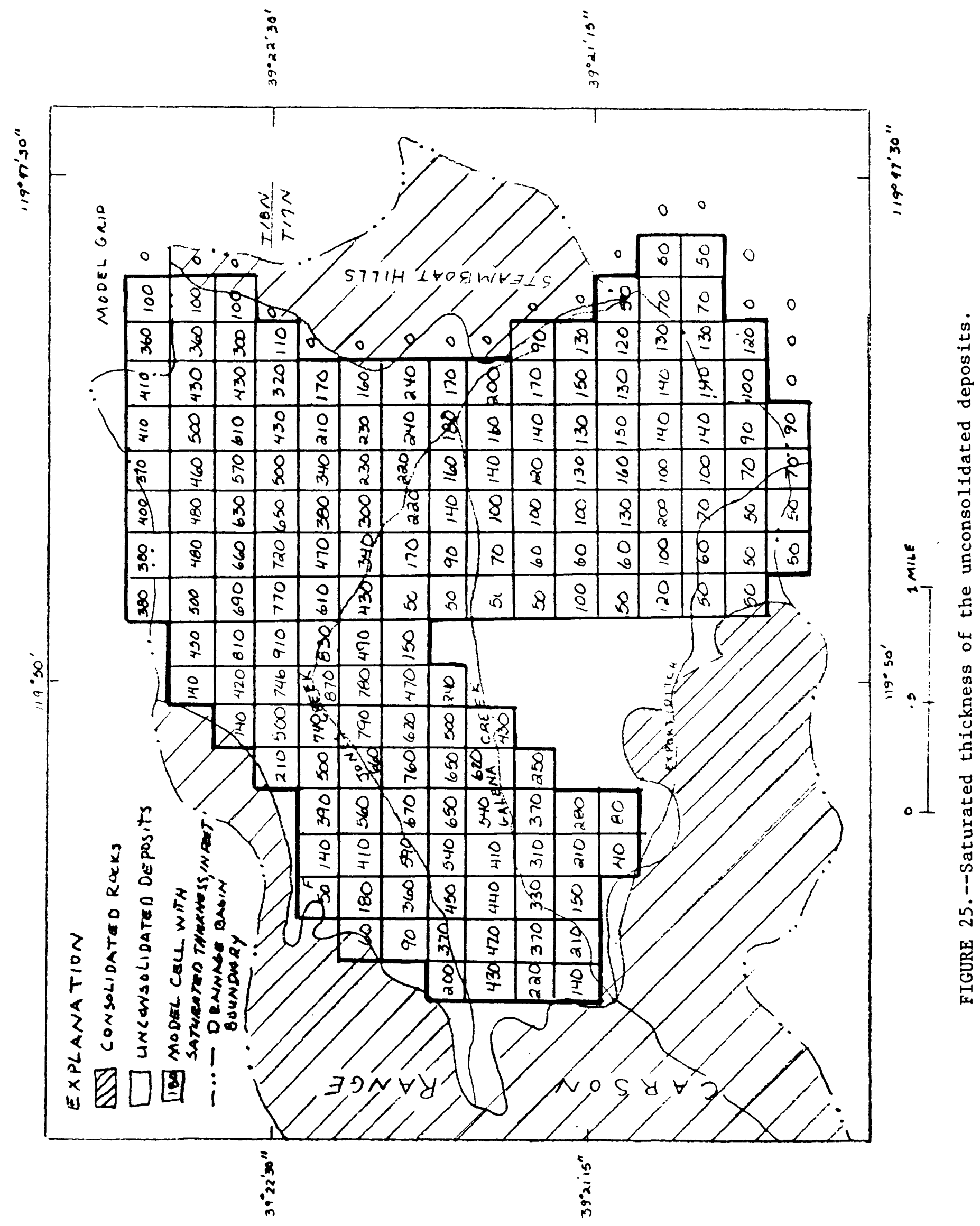


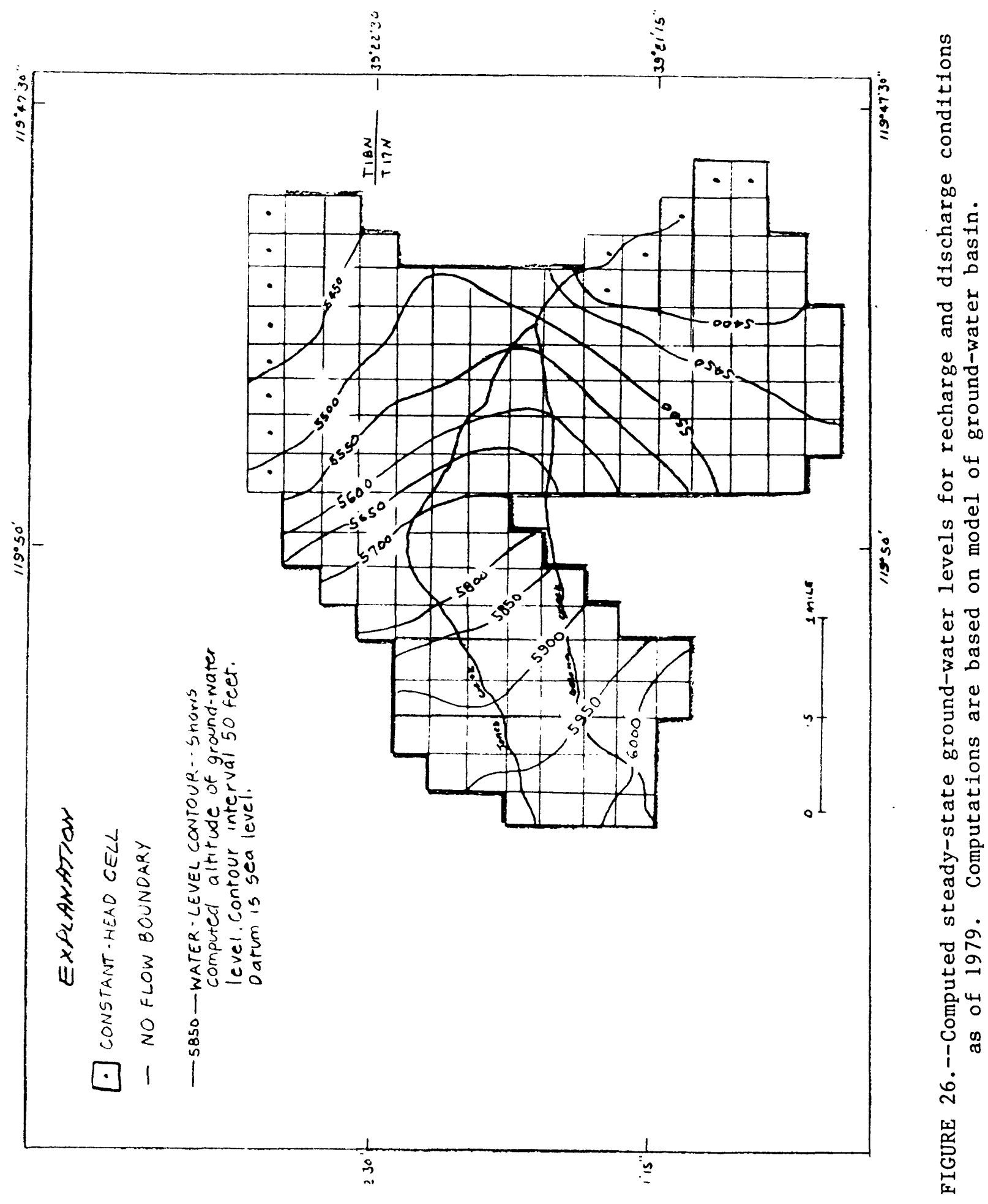


The model was calibrated assuming that the amount and distribution of recharge was known. The model solution is not unique because it was calibrated assuming constant (steady-state) hydrologic conditions. The same results could be obtained by simply varying recharge and hydraulic conductivity proportionally. The model results are based on known information and constitute a best fit of the data. Undoubtedly, the results could be improved with the availability of additional data.

The major purpose for the development of the model was to evaluate roughly ground-water outflow from the Galena Creek ground-water basin. The model may be used to estimate the proportion of total ground-water outflow that crosses each of the two constant-head boundaries. On the basis of the ground-water recharge estimates from table 4, the model indicates that the outflow is 2,700 acre-ft/yr across the northern boundary of the ground-water basin and 1,700 acre-ft/yr across the eastern boundary. However, part of the flow computed as crossing the northern boundary may move into the volcanic rocks of the Steamboat Hills, and then to Pleasant Valley or the Steamboat Springs area, or both.

\section{Accuracy of the Hydrologic Data Base}

and Resulting Estimates

It must be emphasized that the water-budget and modeling results given herein are considered only as good as the data base used. The data base for this study is evaluated qualitatively with regard to its accuracy as follows:

\begin{tabular}{|c|c|c|}
\hline $\begin{array}{l}\text { Hyd rologic } \\
\text { i tem }\end{array}$ & $\begin{array}{l}\text { Method used } \\
\text { to define }\end{array}$ & $\begin{array}{l}\text { Oualitative } \\
\text { evaluation }\end{array}$ \\
\hline Precipitation & $\begin{array}{l}\text { Measured values, } \\
\text { extrapolated }\end{array}$ & Good \\
\hline $\begin{array}{l}\text { Streamflow } \\
\text { Ground-water recharge }\end{array}$ & $\begin{array}{l}\text { Measured and estimated } \\
\text { Estimated }\end{array}$ & $\begin{array}{l}\text { Poor/good } \\
\text { Fair }\end{array}$ \\
\hline $\begin{array}{l}\text { Ground-water recharge } \\
\text { Water-table configuration }\end{array}$ & $\begin{array}{l}\text { Measured water levels, } \\
\text { extrapolated }\end{array}$ & Fair \\
\hline Depth to bedrock & Geophysics & Fair \\
\hline Saturated thickness & $\begin{array}{l}\text { Geophysics and water- } \\
\text { level measurements }\end{array}$ & Fair \\
\hline Hydraulic conductivity & Estimated & Poor/fair \\
\hline Transmissivity & Estimated & Poor/fair \\
\hline Pumpage & Estimated & Good \\
\hline
\end{tabular}

Although several of the components are assumed to have good accuracy, the budget and model results are dependent on the accuracy of the more sensitive hydrologic data--in this case, streamflow, hydraulic conductivity, and transmissivity. The accuracy of these items could have been improved by installing several streamflow gaging stations and by aquifer testing, both of which were beyond the scope of this study. 


\section{SUMMARY}

The source of all water in the Galena Creek drainage basin is precipitation. That precipitation is about 32,000 acre-ft/yr of water, and about 22,000 acre-ft/yr is consumed by evapotranspiration. The residual, about 10,000 acre-ft/yr, defines the available local surface- and ground-water inflow to the basin.

The estimated water inflow is distributed annually within the ground-water basin as follows. Surface-water flow: (1) About 8,100 acre-feet enters the basin as Galena Creek streamflow, (2) about 1,000 acre-feet from Galena Creek is exported from the basin, and (3) about 3,700 acre-feet leaves the basin as Galena Creek streamflow. Ground-water flow: (1) About 3,000 acre-feet becomes primary recharge to the ground-water system (including recharge from Galena Creek), (2) about 1,600 acre-feet becomes secondary recharge to the groundwater system, (3) about 2,700 acre-feet leaves the basin as underflow across the northern and possibly northeastern boundaries, and (4) about 1,700 acrefeet leaves the basin as seepage and spring discharge into Galena Creek and underflow into the Steamboat Hills near the eastern boundary of the basin. Additionally, about 940 acre-feet leaves the basin as evapotranspiration of irrigation water and domestic pumpage. These budget values are listed in tables 4 and 6 and are shown in figure 23.

Any additional use of the available water resource will result in a change in the surface-water and ground-water system. The magnitude of the change will be dependent on the location, type, and amount of use. 
TABLE 7.--Waterlevel altitude in wells, April 30-May 23, 1979

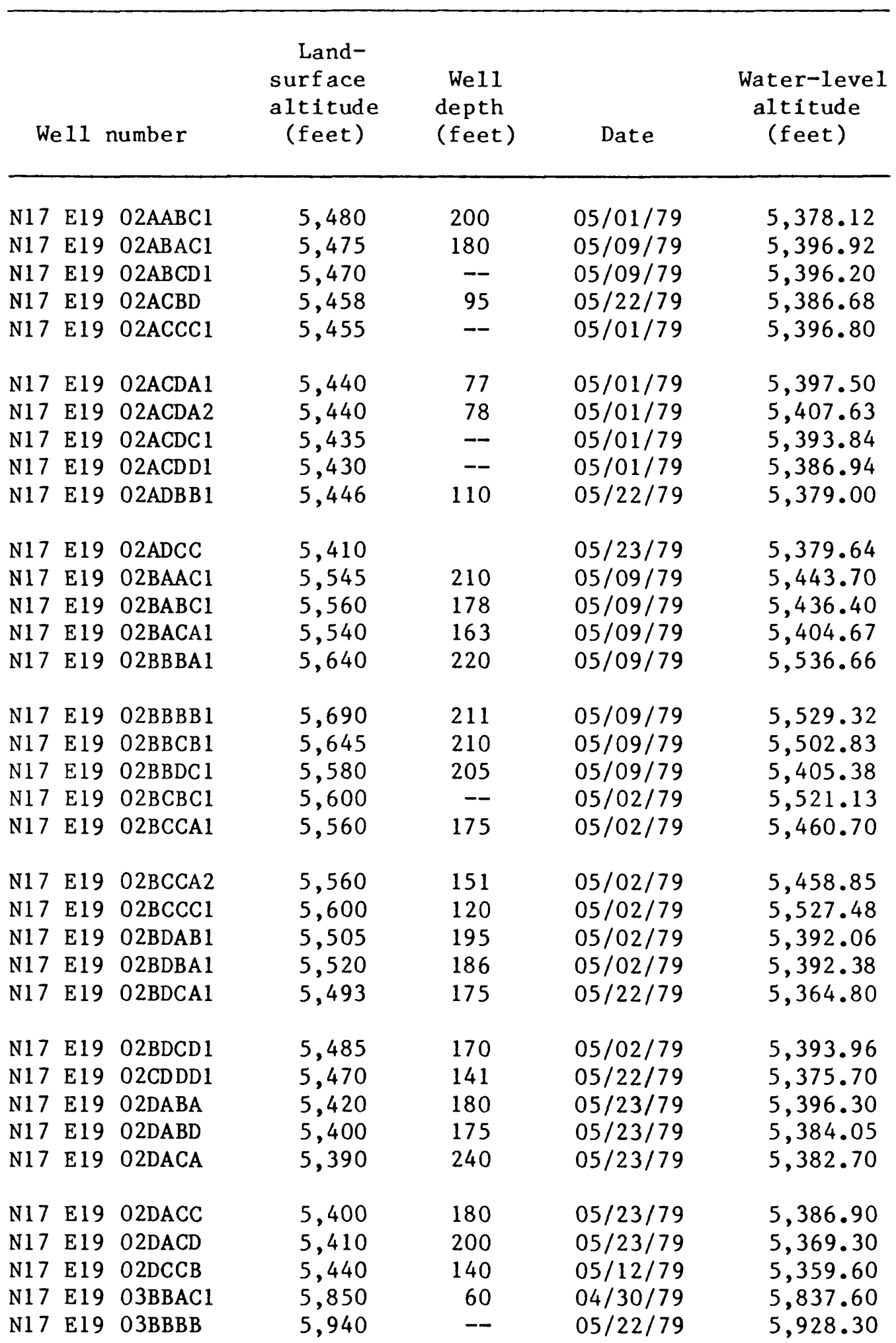


TABLE 7.--Water-level altitude in wells, April 30-May 23, 1979--Continued

\begin{tabular}{|c|c|c|c|c|c|}
\hline We 11 & number & $\begin{array}{l}\text { Land- } \\
\text { surface } \\
\text { altitude } \\
\text { (feet) }\end{array}$ & $\begin{array}{c}\text { Well } \\
\text { depth } \\
\text { (feet) }\end{array}$ & Date & $\begin{array}{l}\text { Water-level } \\
\text { altitude } \\
\text { (feet) }\end{array}$ \\
\hline N17 E19 & 9 03BBBCl & 5,980 & 90 & $04 / 30 / 79$ & $5,930.50$ \\
\hline N17 E19 & $903 \mathrm{BBCB} 2$ & 5,910 & 140 & $04 / 30 / 79$ & $5,860.00$ \\
\hline N17 E19 & 9 03DCDD & 5,710 & 300 & $05 / 22 / 79$ & $5,463.00$ \\
\hline N17 E19 & 9 09AABD 1 & 6,040 & 125 & $04 / 30 / 79$ & $6,037.10$ \\
\hline N17 E19 & 09ABBB & 6,155 & 109 & $05 / 23 / 79$ & $6,093.00$ \\
\hline N17 E19 & 9 09ACCB 1 & 6,200 & 175 & $04 / 30 / 79$ & $6,147 \cdot 30$ \\
\hline N17 E19 & 9 09BAAA & 6,200 & - & $05 / 22 / 79$ & $5,953.50$ \\
\hline N17 E19 & 09CBACl & 6,510 & 67 & $04 / 30 / 79$ & $6,476.30$ \\
\hline N17 E19 & $10 \mathrm{ADBC} 1$ & 5,710 & -- & $05 / 22 / 79$ & $5,462.80$ \\
\hline N17 E19 & 9 1ODABC & 5,705 & - & $05 / 22 / 79$ & $5,486.00$ \\
\hline N17 E19 & $11 \mathrm{ADCC}$ & 5,377 & 150 & $05 / 12 / 79$ & $5,282.40$ \\
\hline N17 E19 & $11 \mathrm{ADDB} 1$ & 5,325 & 75 & $05 / 12 / 79$ & $5,286.20$ \\
\hline N18 E19 & 25CCAD 1 & 5,389 & - & $05 / 22 / 79$ & $5,367.80$ \\
\hline N18 E19 & $925 \mathrm{CCDA} 2$ & 5,400 & 85 & $05 / 22 / 79$ & $5,348.60$ \\
\hline $\mathrm{N} 18 \mathrm{E} 19$ & $25 \mathrm{CDACl}$ & 5,345 & 149 & $05 / 12 / 79$ & $5,208.43$ \\
\hline $\mathrm{N} 18 \mathrm{E} 19$ & $26 \mathrm{CACC} 1$ & 5,690 & 355 & $05 / 10 / 79$ & $5,396.83$ \\
\hline N18 E19 & $26 \mathrm{DBBB} 1$ & 5,555 & 250 & $05 / 10 / 79$ & $5,353.02$ \\
\hline N18 E19 & 26DBDC 1 & 5,555 & 235 & $05 / 12 / 79$ & $5,336.22$ \\
\hline N18 E19 & 26DCBB 1 & 5,590 & 300 & $05 / 10 / 79$ & $5,352.38$ \\
\hline $\mathrm{N} 18 \mathrm{E} 19$ & 26DCCB 1 & 5,595 & 272 & $05 / 12 / 79$ & $5,348.00$ \\
\hline N18 E19 & 27DACAl & 5,815 & 210 & $05 / 12 / 79$ & $5,681.45$ \\
\hline N18 E19 & 27DADAl & 5,780 & 390 & $05 / 12 / 79$ & $5,420.15$ \\
\hline N18 E19 & 34ADCD 1 & 5,825 & 400 & $04 / 30 / 79$ & $5,474.10$ \\
\hline N18 E19 & $934 \mathrm{CCCAl}$ & 6,040 & 135 & $05 / 22 / 79$ & $5,980.73$ \\
\hline N18 E19 & $34 \mathrm{CDDB}$ & 5,790 & 200 & $05 / 22 / 79$ & $5,673.55$ \\
\hline N18 E19 & $34 \mathrm{DDBC} 1$ & 5,765 & 256 & $04 / 30 / 79$ & $5,570.50$ \\
\hline N18 E19 & $36 \mathrm{BCAB} 1$ & 5,470 & 125 & $05 / 08 / 79$ & $5,374.80$ \\
\hline N18 E19 & $36 \mathrm{BCCD} 1$ & 5,520 & -- & $05 / 04 / 79$ & $5,417.60$ \\
\hline N18 E19 & $36 \mathrm{CBCA}$ & 5,470 & 180 & $05 / 22 / 79$ & $5,365.50$ \\
\hline N1 8 E19 & $36 \mathrm{CCDD} 1$ & 5,480 & 125 & $05 / 04 / 79$ & $5,383.80$ \\
\hline N18 E19 & $36 \mathrm{CCDD} 2$ & 5,495 & 175 & $05 / 04 / 79$ & $5,380.10$ \\
\hline
\end{tabular}




\section{REFERENCES CITED}

Arteaga, F. E., and Durbin, T. D., 1978, Development of a relation for steady-state pumping rate for Eagle Valley ground-water basin, Nevada: Geological Survey Open-File Report 79-261, 44 p.

Chapman, R. H., 1966, Gravity base network: California Division of Mines and Geology Special Report 90, 49 p.

Crewdson, R. A., 1976, Geophysical studies in the Black Rock geothermal prospect, Nevada: Golden, Colorado School of Mines, unpublished Ph. D. thesis, $180 \mathrm{p}$.

Desormier, W. L., 1983, Steamboat Springs geothermal project, in Field Trip \#2, Reno NV to Steamboat Springs, NV: Reno, Nev., Symposium on the Role of Heat in the Development of Energy and Mineral Resources in the Northern Basin and Range Province, May 16-18, 1983, p. 27-30.

Glancy, P. A., and Katzer, T. L., 1975, Water-resources appraisal of the Carson River basin, western Nevada: Nevada Division of Water Resources, Reconaissance Report 59, 126 p.

Harrill, J. R., 1973, Evaluation of the water resources of Lemmon Valley, Washoe County, Nevada: Nevada Division of Water Resources Bulletin 42, $130 \mathrm{p}$.

Hayford, J. F., and Bowie, William, 1912, The effect of topography and isostatic compensation upon the intensity of gravity: U.S. Coast and Geodetic Survey Special Publication 10, 132 p.

Plouff, Donald, 1977, Preliminary documentation for a FORTRAN program to computer gravity terrain corrections based on topography digitized on a geographic grid: U.S. Geological Survey Open-File Report 77-535, 45 p.

Rantz, S. E., 1974, Mean annual runoff in the San Francisco Bay region, California, 1931-70: U.S. Geological Survey Miscellaneous Field Studies Map MF-613.

Rush, F. E., 1968, Index of hydrographic areas: Nevada Division of Water Resources, Information Report 6, $35 \mathrm{p}$.

Tabor, R. W., and Ellen, S., 1975, Geologic map, Washoe City quadrangle [Nevada]: Nevada Bureau of Mines and Geology Urban Maps Series, Washoe City Folio, Map 5Ag.

Thompson, G. A., and White, D. E., 1964, Regional geology of the Steamboat Springs area, Washoe County, Nevada: U.S. Geological Survey Professional Paper 458-A, 52 p. 
Trescott, P. C., 1975, Documentation of finite-difference model for simulation of three-dimensional ground-water flow: U.S. Geological Survey Open-File Report 75-438, 85 p.

Trescott, P. C., and Larson, S. P., 1976, Supplement to Open-File Report 75-438, documentation of finite-difference model for simulation of three-dimensional ground-water flow: U.S. Geological Survey Open-File Report 76-591, 21 p.

U.S. Geological Survey, 1963, Surface water records of Nevada, 1962: Carson City, Nev., U.S. Geological Survey water-data report, $132 \mathrm{p}$.

- 1967, Water resources data for Nevada, 1966: Carson City, Nev., U.S. Geological Survey water-data report, 203 p.

- - 1980, Water resources data for Nevada, water year 1979: U.S. Geological Survey Water-Data Report NV-79-1, 388 p.

--- [in press], Water resources data for Nevada, water year 1983: U.S. Geological Survey Water-Data Report.

Van Denburgh, A. S., Lamke, R. D., and Hughes, J. L., 1973, A brief water-resources appraisal of the Truckee River basin, western Nevada: Nevada Division of Water Resources, Reconnaissance Report 57, 122 p.

Zodhy, A. A. R., Eaton, G. P., and Mabey, D. R., 1974, Application of surface geophysics to ground-water investigations: U.S. Geological Survey Techniques of Water-Resource Investigations, Book 2, Chapter DI, 116 p. 